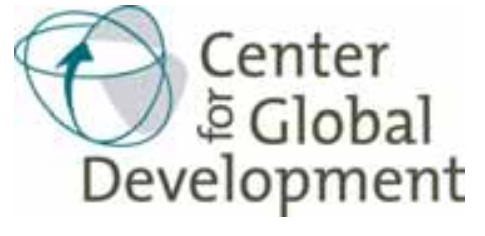

Working Paper Number 172

May 2009

\title{
Rice Price Formation in the Short Run and the Long Run: The Role of Market Structure in Explaining Volatility
}

C. Peter Timmer

Abstract
This paper analyzes price formation on the world's rice market using simple supply
and demand models as a start, but moving to "supply of storage" models-a staple
of commodity-market analysis for more than half a century-to explain hoarding
behavior and its subsequent impact on prices. The supply of storage model,
however, does not account adequately for the influence that "outside" speculators
have on prices. This paper quantifies the impact of financial factors and actors on
commodity-price formation using very short-run prices and Granger causality
analysis for a wide range of financial and commodity markets, including rice. The
results are highly preliminary but are also very provocative. Speculative money
seems to surge in and out of commodity markets, strongly linking financial variables
with commodity prices during some time periods, but these periods are often short
and the relationships disappear for long periods of time. Finally, the paper addresses
the long-run (since 1900) relationships among the prices of the three basic cereal
staples, rice, wheat and corn (maize), which have declined more than 1 percent per
year over the past century. The decline accelerated after the mid-1980s; only the
recent run-up in cereal prices in $2007-08$ returned them to the long-run downward
trend. Despite these common features and important cross-commodity linkages,
however, price formation for rice has several unique dimensions worthy of further
study.

The Center for Global Development is an independent, nonprofit policy research organization that is dedicated to reducing global poverty and inequality and to making globalization work for the poor.

Use and dissemination of this Working Paper is encouraged; however, reproduced copies may not be used for commercial purposes. Further usage is permitted under the terms of the Creative Commons License. The views expressed in this paper are those of the author and should not be attributed to the board of directors or funders of the Center for Global Development. This paper was made possible in part by support from the William and Flora Hewlett Foundation. 
C. Peter Timmer. 2009. "Rice Price Formation in the Short Run and Long Run: The Role of Market Structure in Explaining Volatility." CGD Working Paper 172. Washington, D.C.: Center for Global Development.

http://www.cgdev.org/content/publications/detail/1422136/ 


\title{
Rice Price Formation in the Short Run and the Long Run: The Role of Market Structure in Explaining Volatility
}

\author{
C. Peter Timmer ${ }^{1}$
}

\section{Introduction}

The formation of rice prices in world markets has long interested scholars and policy makers. ${ }^{2}$ Nearly half the world's population consumes rice as a staple food and it is typically produced by small farmers in Asia using highly labor-intensive techniques. (Ninety percent of the world's rice harvest is produced in Asia.) Rice is mostly consumed within a short distance of where it is produced, with international trade less than 30 million metric tons (mmt) out of a global production of nearly $440 \mathrm{mmt}$ (milled rice equivalent) - only 7-8 percent of rice produced crosses an international border. ${ }^{3}$ Still, the world market for rice provides essential supplies to importing countries around the world, and the prices set in this market provide signals to both exporting and importing countries about the opportunity cost of increasing production and/or consumption. It is disconcerting to exporters and importers alike if these market signals are highly volatile.

Part of the longstanding interest in the world rice market has been precisely because it has been so volatile. The coefficient of variation of world rice prices has often been double that of wheat or corn for decades at a time. ${ }^{4}$ Understanding this volatility has been difficult because much of it traces to the residual nature of the world rice market, as both importing and exporting countries stabilize rice prices internally by using the world rice market to dispose of surpluses or to meet deficits via imports. Thus supply and demand in the world market are a direct result of political decisions in a number of Asian countries. Rice is a very political commodity (Timmer and Falcon, 1975).

But volatility in rice prices is also driven by the structure of rice production, marketing and consumption in most Asian countries, that is, by the industrial organization of the rice economy. Hundreds of millions of small farmers, millions of traders, processors and retailers, and billions of individual consumers all handle a commodity that can be stored for well over a year in a

\footnotetext{
${ }^{1}$ An early version of this paper was prepared for the FAO conference on "Rice Policies in Asia” held in Chiang Mai, Thailand from February 9-12, 2009 (Timmer, 2009). A review of the causes of high food prices in Asian economies appeared in Timmer (2008a) and an early version of the analytical perspective developed here was presented in Timmer (2008b). I would like to thank David Dawe, Tom Slayton, Ralph Cummings, Wally Falcon, Michael Clemens, Nora Lustig, Keith Jones, and participants at a World Food Program seminar in Rome on "Food, Finance and the Future: Is food just another financial instrument?” January 26, 2009 for helpful comments. Robin Kraft at CGD provided essential research assistance. The views, and mistakes, expressed are my own. Contact at ptimmer@cgdev.org.

${ }^{2}$ The early standard works are Wickizer and Bennet (1941) and Barker and Herdt (with Beth Rose) (1985).

${ }^{3}$ Information on the world rice market is available at http://usda.mannlib.cornell.edu/usda/ers/89001

${ }^{4}$ See the discussion of long-run price trends for rice, wheat and corn (maize) at the end of this paper, and Table 2 for statistical results.
} 
consumable form if properly milled and warehoused. ${ }^{5}$ The price expectations of these market participants are critical to their decisions about how much to grow, to sell, to store and to consume. Because there are virtually no data available about either these price expectations or their marketing consequences, the world rice market operates with highly incomplete and imperfect information about short-run supply and demand factors. In this, rice is a very different commodity from the other basic food staples, wheat and maize. ${ }^{6}$

When the political dimensions and the different market structure for rice are integrated into actual price formation, the scope for extreme volatility is clear. Understanding the proximate causes of unstable rice prices requires understanding both factors, and how they contribute to the formation of price expectations on the part of market participants. These expectations can drive “destabilizing speculative behavior" among millions, even billions, of market participants, such that price formation seems to have a large, destabilizing, speculative component. ${ }^{7}$ If so, and price behavior late in 2007 and early 2008 suggests this might be a serious problem, what stabilizing activities might be taken to make the world rice market a more reliable venue for imports and exports, with price signals that reflect long-run production costs and consumer demand rather than short-run panicked behavior?

The immediate question, then, is did speculative behavior destabilize the formation of rice prices during the rapid escalation of prices in world markets late in 2007 and early in 2008? Although debated at the time, in retrospect-after the sudden collapse of most commodity prices and the rapid decrease in rice prices between June and August--the answer is easy. Of course it did. The questions now are how much, through what mechanisms, what happens as these influences unwind, and how is the story for rice different from other commodities?

To answer these questions, this paper addresses four separate topics, each linked to the others by basic mechanisms of price formation. Simple supply and demand models are a start, and are developed in the next section. The difference between short run responses to price changes, and those responses after full adaptation is possible in the long run, is crucial and the conceptual

\footnotetext{
${ }^{5}$ The oxidation of traces of bran on milled rice can significantly reduce the shelf life of rice stored in the tropics.

${ }^{6}$ This difference was pointed out clearly in Jasny’s classic study of Competition Among Grains (Jasny, 1940). He justifies his exclusion of rice from the study with the following observation: "The Orient is a world by itself, with its own climate, diet, and economic and social setup, and this makes it easy for us to omit it. The inclusion of rice would mean the discussion of two worlds. The writer would be satisfied to have mastered one.” (p. 7) The sharp difference between rice-based economies and those based on wheat or corn is also stressed by Bray (1986) and Oshima (1987).

${ }^{7}$ The emphasis here on destabilizing expectations and subsequent speculative price behavior is meant to contrast with the normally stabilizing role that routine speculative activities play. Unless speculators buy during the harvest, store grain, and sell during the off season, seasonal price movements would be much larger than they are without these normal speculative activities. Of course, seasonal prices must rise from their harvest lows to their peak just before the new harvest, or these stabilizing speculative investments would not be made. It is difficult to define precisely the difference between stabilizing and destabilizing speculation. Even agents who engage entirely in the financial derivatives of commodities, such as futures, options and swaps, can contribute to the liquidity of the underlying markets and thus help support the stabilizing function of speculation. But when herd behavior sets in and most financial speculation is in only one direction, the potential to generate bubbles and less stable prices is clear. Much more analytical and empirical work needs to be done on the role of financial instruments as they influence commodity prices in spot markets (Robles, Torero and von Braun, 2009).
} 
model highlights the importance of these differences for understanding current prices. History matters.

But storage and price expectations also become important for storable commodities in the short run - the length of time the commodity can be stored-about a year for rice. A model of the "supply of storage," a staple of commodity market analysis for more than half a century, is used to understand the factors affecting price expectations, and price formation, in the short run. This model is very powerful in its ability to explain hoarding behavior and subsequent impact on prices.

The supply of storage model is less successful in explaining the impact on spot market prices of futures market prices that are driven by "outside" speculators, i.e. those who have no interests in owning the actual commodity but are investing solely on the basis of expected price changes on futures markets. The role of outside speculators in commodity price formation is an old debate, although one that has usually not included rice because of the thinness of rice futures markets. The potential of outside speculators to induce destabilizing price formation is a major element of this debate.

Next, this debate over the role of speculation is revived in an effort to understand the impact of financial factors and actors on commodity price formation using very short run prices and Granger causality analysis, for a wide range of financial and commodity markets, including rice. These results are highly preliminary, but are also very provocative. Speculative money seems to surge in and out of commodity markets, strongly linking financial variables with commodity prices during some time periods. But these periods are often short and the relationships disappear entirely for long periods of time.

The links between financial markets and commodity markets are not simple nor are they stable. Much more research is needed to understand both the short-run and long-run linkages between financial and (food) commodity markets. Appendix 1 examines Granger Causality links between exchange rates and commodity prices. Appendix 2 takes the analysis another step by examining price linkages across commodities using the same dataset and Granger Causality techniques. The results are new and interesting, if still poorly understood, as strong cross-commodity price linkages also come and go.

Finally, the paper addresses the long-run relationship between prices of the three basic cereal staples, rice, wheat and corn (maize), since 1900. It is clear there has been a long-run decline in the prices of all three cereals. There is a basic commonality in this decline, as all three commodities have trend price declines of more than 1.0 percent per year over the past century. Further, this decline accelerated after the mid-1980s, again for apparently common reasons. Only the recent run-up in cereal prices in 2007-08 returned them to the long-run downward trend. Despite these common features, however, and important cross-commodity linkages, price formation for rice has several unique dimensions that are also worthy of further study. 


\section{The analytics of food price formation}

Understanding causation in food price formation implies an empirically refutable model of mechanisms of action. For food prices, this means an analytical model based on supply and demand mechanisms with equilibrium prices derived from basic competitive forces. There are many such models in existence (IFPRI, FAPRI, MOMAGRI, FAO, USDA), but none that address the specific issues in this paper (Munier, 2008; Trostle, 2008).

Here we seek to understand the contribution from a wide range of basic causes to price formation for three important staple food grains - rice, wheat, and corn. ${ }^{8}$ Some of these causes may be exogenous, e.g. weather shocks or legislated mandates for bio-fuel usage. But many will be endogenous, e.g. responses of producers and consumers to prices themselves, perhaps even policy responses of governments to prices. Export bans for rice as a way to prevent domestic food price inflation are an obvious example (Brahmbhatt and Christiaensen, 2008; Slayton and Timmer, 2008; Slayton, 2009).

The model of price formation developed here attempts to incorporate all of these factors in a rigorous enough way to bring data to bear on answering the key question: what caused the recent run-up in world market prices for these basic commodities, and why did prices subsequently come down so sharply? For several of the factors, the answers remain more impressionistic than statistical, but we push the statistical approach as far as it will go (perhaps too far; see the Granger Causality tests below).

\section{A simple model of price formation to use as a heuristic device}

Consider the most basic model of commodity price formation that is capable of illuminating our problem.

$$
\begin{aligned}
& D_{t}=f\left(a_{t}, P_{t}, s r_{d}, P_{t-n}, l r_{d}\right)=a_{t} P_{t}^{s r_{d}} P_{t-n}^{l r_{d}} \\
& S_{t}=g\left(b_{t}, P_{t}, s r_{s}, P_{t-n}, l r_{s}\right)=b_{t} P_{t}^{s r_{s}} P_{t-n}^{l r_{s}}
\end{aligned}
$$

where $D_{t}=$ demand for the commodity during time $t$; $S_{t}=$ supply of the commodity during time $t$; $f$ and $g=$ functional forms for demand and supply functions, respectively; $a_{t}=$ time-dependent shifters of the demand curve; $b_{t}=$ time-dependent shifters of the supply curve; $P_{t}=$ equilibrium market price during time $t ; P_{t-n}=$ market price during some previous time period $t-n$; and, $s r_{d}, s r_{s}$, $I r_{d}$ and $l r_{s}=$ indicators that demand and supply responses will vary depending on whether they are in the short run $s r$ or long run $l r$. In the specification below, these will be short-run and longrun supply and demand elasticities. ${ }^{9}$

In short run equilibrium, $D_{t}=S_{t}$. For simplicity (and the ability to work directly with supply and demand elasticities), assume the demand and supply functions are Cobb-Douglas. Then

\footnotetext{
${ }^{8}$ Price formation for palm oil is also analyzed to some extent because of its role in meeting bio-diesel mandates in Europe.

${ }^{9}$ In an empirical specification, the long-run price elasticities would be net of the short-run elasticities.
} 


$$
\log a_{t}+s r_{d} \log P_{t}+l r_{d} \log P_{t-n}=\log b_{t}+s r_{s} \log P_{t}+l r_{s} \log P_{t-n}
$$

Solving for the equilibrium price $P$,

$$
\log P_{t}=\left[\log b_{t}-\log a_{t}\right] /\left[s r_{d}-s r_{s}\right]+\log P_{t-n}\left[l r_{s}-l r_{d}\right] /\left[s r_{d}-s r_{s}\right]
$$

Taking first differences to see the factors that explain a change in price from $t-1$ to $t$ reveals a somewhat complicated result:

$$
\begin{array}{r}
d \log P_{t}=\left\{\left[\log b_{t}-\log b_{t-1}\right]-\left[\log a_{t}-\log a_{t-1}\right]\right\} /\left[s r_{d}-s r_{s}\right]+ \\
{\left[\log P_{t-n}-\log P_{t-(n+1)}\right]\left[l r_{s}-l r_{d}\right] /\left[s r_{d}-s r_{s}\right],}
\end{array}
$$

where $d \log P_{t}=$ the percentage change in price from time period $t-1$ to time period $t$ (for relatively small changes). This is what we are trying to explain. What "causes" changes in $d \log P_{t}$ ? Why are food prices high (or low)?

To answer these questions, it helps to simplify the equation. Let $S R=$ the net short-run supply and demand response $s r_{d}-s r_{s}$, which is always negative because $s r_{d}<0$ and $s r_{s}>0$.

Let $L R=$ the net long-run supply and demand response $l r_{s}-l r_{d}$, which is always positive, for similar reasons (note that the demand coefficient is subtracted from the supply coefficient in this case, the opposite from the short-run coefficients above).

Let $d \log b_{t}=\log b_{t}-\log b_{t-1}$, which for small changes is the percentage change in the supply shifters.

Let $d \log a_{t}=\log a_{t}-\log a_{t-1}$, which for small changes is the percentage change in the demand shifters.

Finally, let $d \log P_{t-n}=\log P_{t-n}-\log P_{t-(n+1)}$, which for small changes is the percentage change in the commodity price for some specified number of time periods in the past, for example, five or 10 years (after which the long-run producer and consumer responses to price have been fully realized). ${ }^{10}$

Combining all of these new definitions, we have a simpler equation explaining percentage changes in commodity prices:

Percent change in $P_{t}=$ [percent change in $b_{t}$ - percent change in $\left.a_{t}\right] / S R$

+ [percent change in $P_{t-n}$ ] LR/SR

\footnotetext{
${ }^{10}$ It would be possible to specify this model with specific time lags that add up to the long-run response, and such an approach would improve the empirical validity of this model. The purpose here, however, is to clarify a conceptual point, that historical prices have current significance because of both behavioral and technological lags in the response by producers and consumers to these prices. An empirical specification would also permit the development of a formal definition of when speculative activity is destabilizing and thus allow for statistical hypothesis testing. Pursuing this line of thought very far, however, immediately brings the discussion into the financial "bubble" literature, which is robust but inconclusive. An early but insightful review is by Shiller (1992).
} 
The "surprising" result is how simple the answer appears to be. There are four key drivers:

(1) the relative size of changes in $a_{t}$ to $b_{t}$, i.e. factors shifting the demand curve relative to factors shifting the supply curve;

(2) the relative size of short-run supply and demand elasticities $\left(s r_{s}\right.$ and $\left.s r_{d}\right)$;

(3) the relative size of long-run supply and demand elasticities ( $l r_{s}$ and $\left.l r_{d}\right)$; and

(4) how large (and what sign) the price change was in earlier time periods.

\section{Why the analytics matter}

A simple numerical example, with plausible parameters, shows the power of this "explanatory" equation. Assume the following numerical parameters for purposes of illustration:

$$
\begin{aligned}
& s r_{d}=-0.10 \\
& s r_{s}=+0.05 \\
& l r_{d}=-0.30 \\
& l r_{s}=+0.50
\end{aligned}
$$

These values imply that $S R=-0.15$ and $L R=0.80$.

The short-run elasticities assumed here are quite low, but realistic for annual responses. Demand responds $1 \%$ for a $10 \%$ change in price; supply only responds by half a percent to a similar $10 \%$ price change (the signs, of course, are negative for demand and positive for supply responses).

The long-run elasticities are also on the low side of econometric estimates, but again, seem realistic for a world facing increasing resource constraints. Although some estimates of long-run supply response are quite high-approaching unity or higher, these were estimated for time periods when acreage expansion was significant and fertilizer usage was just becoming widespread (Peterson, 1979). In principle, these long-run elasticities are net of the short-run elasticities.

Assume, as seems to be the case since the early 2000s, that demand drivers have been larger than supply drivers. A reasonable estimate is that demand has been shifting out by $3.0 \%$ per year and supply shifting out just $1.5 \%$ per year. A (partial) example of such a growing imbalance between demand (population growth) and supply (yields) for rice in Asia is shown in Figure 1. Finally, assume that prices in the past have been "low," so the change in $P_{t-n}$ is $-10.0 \%$. What do all these parameters mean for current price change? 
Figure 1. Annual average percentage increase in rice yields and population between successive rolling 5-year periods in rice-producing Asia

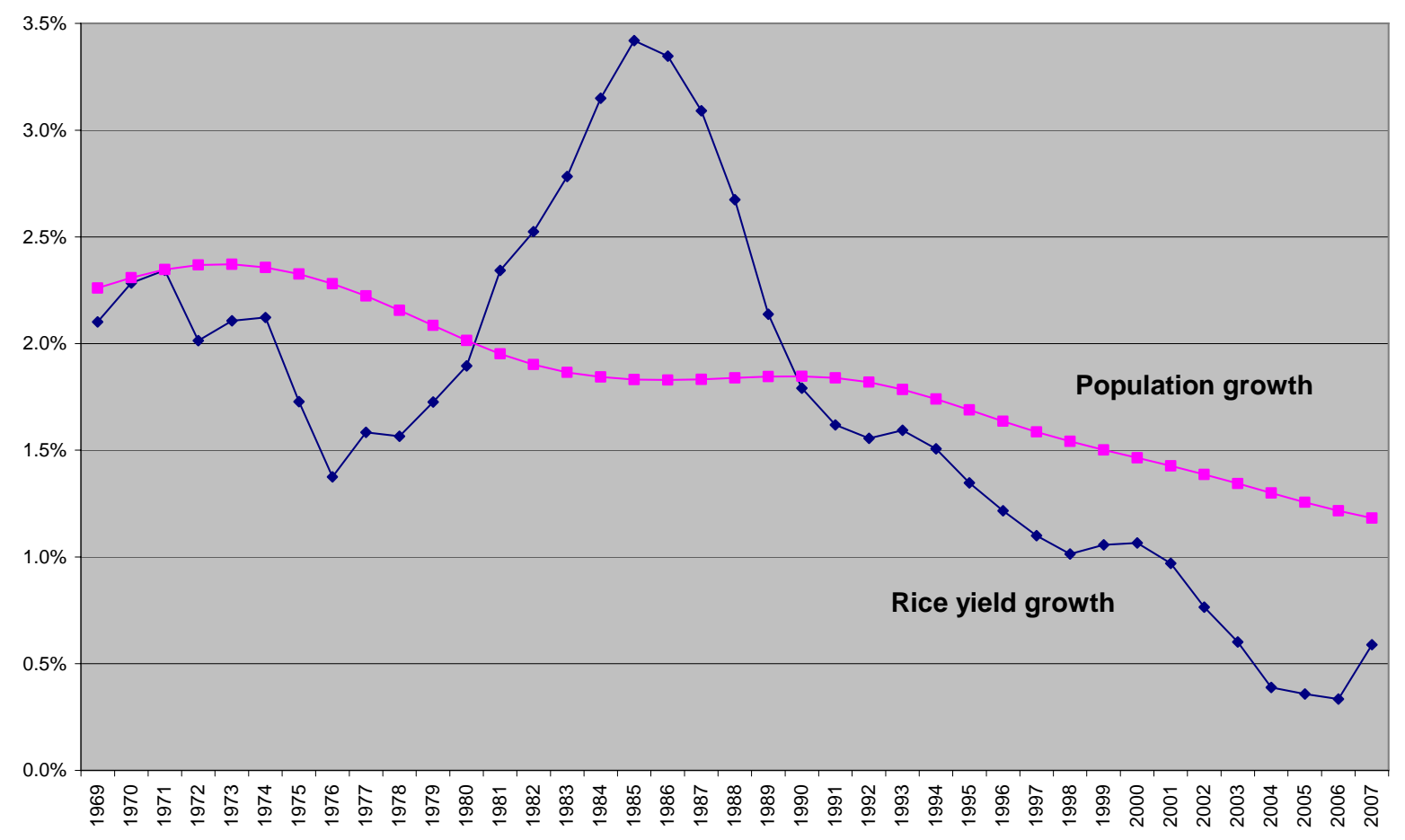

Source of raw data: USDA for yields, FAO for population [Chart from Dawe, 2008c]

The figure shows the annual average percentage change in yields and population. For example, the data for 1969 are the change between 1965-69 and 1960-64. Rice producing Asia is an aggregate of seventeen large Asian countries (Bangladesh, Cambodia, China, DPR Korea, India, Indonesia, Japan, Laos, Malaysia, Myanmar, Nepal, Pakistan, Philippines, Republic of Korea, Sri Lanka, Thailand, and Viet Nam).

Plugging these values into the price change equation yields the following result:

$$
\text { Percent change in } \begin{aligned}
P_{t} & =[1.5 \%-3.0 \%] /-0.15+[-10.0 \%] 0.80 /-0.15 \\
& =[10.0 \%]+[53.3 \%] \\
& =63.3 \% \text { higher. }
\end{aligned}
$$

This is a very dramatic result. The imbalance between "current” supply and demand drivers causes the price to rise by $10 \%$, but the historically low prices (and "only" a $10 \%$ decline in the earlier period) cause current prices to be $53 \%$ higher, as the long-term, lagged response from producers and consumers to these earlier low prices has a very large quantitative impact. Much of the slow run-up in food prices from 2003 to 2007 would seem to be caused by producers and consumers gradually responding (i.e. reflecting their "long-run" responses) to earlier episodes 
of low prices, especially from the late 1990s until about 2003. For example, between 1996 and 2001 the real price of rice declined by $14.7 \%$ per year!

These results are obviously sensitive to the values assumed for the key short-run and long-run supply and demand parameters. For example, if the world is running out of land, water, and new agricultural technologies, the assumed long-run supply elasticity of 0.5 might be too high. Reducing it to 0.2 changes the responsiveness of current prices to past episodes of low prices considerably, from a $53.3 \%$ run-up if past prices had been $10 \%$ lower than current prices, to just a $33.3 \%$ run-up. The conclusion is sobering for understanding the causes of the sharp spike in rice prices in late 2007 and early 2008. If less of the run-up is attributable to lagged production response, more is due to destabilizing speculative pressures on short-run price formation. The mechanisms by which such speculative pressures are transmitted to world prices are discussed below.

Over long periods of time, the first driver is clearly most important-how fast is the demand curve shifting relative to the supply curve? At the level of generality specified in this model, the actual underlying causes of these shifts do not matter. All that matters is the net result. If the demand curve is shifting outward by $3 \%$ per year, and the supply curve is shifting out by just $1.5 \%$ per year, the difference of $1.5 \%$ per year will push prices higher, by an amount determined by net short-run supply and demand elasticities with respect to price. The "simple" fact is that commodity price changes are driven by the net of aggregate supply and demand trends, not their composition.

It is important to realize that the analytical model of price formation makes a sharp distinction between factors that shift the demand and supply curves (the $a_{t}$ and $b_{t}$ coefficients), and the responsiveness of farmers and consumers to changes in the market price (the $s r_{s}$ and $s r_{d}$ coefficients), which show up as movements along the supply and demand curve.

Analytically, the distinction is very clear, but empirically it is often hard to tell the difference. If farmers use more fertilizer in response to higher grain prices, should this count as part of the supply response or as a supply shifter? If governments and donor agencies restrict their funding of agricultural research because of low grain prices, is the resulting lower productivity potential a smaller supply shifter a decade later or a long-run response to prices? Whatever the labels, it is important to understand the causes.

\section{The composition of changing demand and supply trends}

This ambiguity can be a serious problem, because it is the composition of changing demand and supply trends that we are seeking to understand, even quantify, as a way to understand the causes of changes in food prices. The list of possible factors is long. For demand, it includes (in order of predictability):

1) Population (driven by demographic transition, fertility, mortality, famine)

2) Income growth (driven by economic policy, trade, technology, governance)

a) Direct consumption

b) Indirect consumption through livestock feeding or industrial utilization 
3) Income distribution (driven by globalization, food prices, agricultural growth, structural transformation)

4) Bio-fuel demands (driven by political mandates and the price of petroleum)

a) Direct demand for maize and vegetable oils

b) Ripple effects on other commodities

5) US dollar depreciation (most commodities on world markets are priced in dollars)

6) Food prices (endogenous, driven by supply/demand balance and technical change; impact felt through the demand elasticities)

7) Private stockholding

a) Commercial (driven by price expectations and supply of storage)

b) Household (driven by price panics and hoarding)

8) Public stockholding (driven by buffer stock policy)
a) Trade policy
b) Procurement policy

9) Financial speculation ${ }^{11}$

a) Futures/options markets and "sophisticated" speculators

b) Role of commodity index funds available to general investors

For supply, the list is not so long, but the factors may be even more difficult to understand and quantify:

1) Area expansion

a) Irrigation and cost of water

b) De-forestation and environmental costs

c) “Benign” area expansion in Africa and Latin America? ${ }^{12}$

\footnotetext{
${ }^{11}$ Very little is known about the use of new financial derivatives by "outside” investors in food commodities. It is clear that many investments take the form of over the counter (OTC) commodity swaps that do not go through any clearing house, and thus do not get reported as open interest by the regulated futures markets. Obtaining better information about these transactions will probably require interviews with market participants.

12 "Benign" refers to expansion of cropped area that is environmentally sustainable and not a significant contributor to long-run climate change.
} 
2) Yield growth

a) Availability and costs of inputs

i) Fertilizer costs

ii) Energy costs

iii) Sustainability issues

b) Seed technology and the GMO debate

c) Management improvements/farmer knowledge

3) Variability

a) Weather

b) Climate change

It would be desirable to put quantitative weights on each of the supply and demand factors in terms of their role in causing price changes for key food commodities: rice, wheat, corn. Other researchers are attempting to do the same thing. The main debates have been over how much bio-fuels and financial speculation caused the sharp run-up in food and oil prices in 2007 and early 2008, after allowance is made for rising demand for basic commodities in rapidly growing developing countries, especially China and India.

A paper by Don Mitchell, Senior Commodity Economist at the World Bank, for example, caused a furor when it was "leaked" to the press in July, 2008: his finding was that perhaps three quarters of the run-up in grain prices was caused by U.S. policy toward ethanol production from corn (Mitchell, 2008). ${ }^{13}$ At the same time, the U.S. Secretary of Agriculture was arguing publicly, at the FAO Food Summit in June, that bio-fuel production played only a minor role in high food prices-2-3 \%. Both explanations cannot be right.

The point is that these are contentious issues with no clearly accepted methodology for resolving them, a point also stressed by Abbot, Hurt and Tyner (2008):

“The factors driving current food price increases are complex. We make no attempt to calculate what percentage of price changes are attributable to the many disparate causes, and, indeed, think it is impossible to do so. [p. 8, emphasis added]"

\footnotetext{
${ }^{13}$ An early draft and PowerPoint presentation based on Mitchell's research were unequivocal that about $3 / 4$ of the run-up in food prices through late 2007 was due to US bio-fuel mandates. The subsequent World Bank Research Paper cited in the references concludes as follows: "These factors explain 25-30 percent of the total price increase, and most of the remaining 70-75 percent increase in food commodities prices was due to biofuels, and the related consequences of low grain stocks, large land use shifts, speculative activity and export bans.” (Mitchell, 2008, p. 17)
} 
The simple model here reveals why. If, for example, population growth is adding $1.5 \%$ per year to demand for a staple food grain, income growth is adding $0.5 \%$ per year to direct demand for that grain, and indirect demand via livestock feeding is adding $1.0 \%$ per year, demand is growing by $3 \%$ per year. If, at the same time, supply is growing by $1.5 \%$ per year $(0.5 \%$ from area expansion and $1.0 \%$ from annual yield growth, for example), the net result is that aggregate demand growth exceeds aggregate supply growth by $1.5 \%$ per year and this will put upward pressure on the equilibrium price of this food grain. Even if lagged prices had been in long-run equilibrium until demand shifters started to outstrip supply shifters, just this imbalance of $1.5 \%$ per year leads to price increases of $10 \%$ per year with the assumed short-run supply and demand elasticities. Between 2001 and 2006, real rice prices increased over 8\% per year on world markets.

\section{What can simple supply and demand models say about the explosion of food prices?}

There is no meaningful way to say what element of demand is growing "too fast" so long as each of the components of demand growth is growing relatively steadily. Indeed, the "blame" for rising grain prices can equally be laid at supply growth that is "too slow." Market clearing prices are driven by the aggregate of supply and demand in that market at a point in time. Prices themselves do not reveal the underlying composition of those supplies and demands (the origin of the classical "identification problem").

This perspective on formation of market prices presents a conundrum. The "slow and steady" shifters of both supply and demand can explain gradual increases in prices, such as seen from the early-2000s until late 2007 (see Figure 2). The lagged response to earlier periods of low prices can explain some acceleration in these prices, especially for rice and wheat. But the explosion in food prices late in 2007 and in the first half of 2008 clearly requires additional explanation involving factors not incorporated in the simple model of price formation just outlined. Much of the additional "analytical" explanation of short-run price movements will be provided from the supply of storage model, with its focus on links between inventory movements and price expectations which can be expressed in futures markets. 


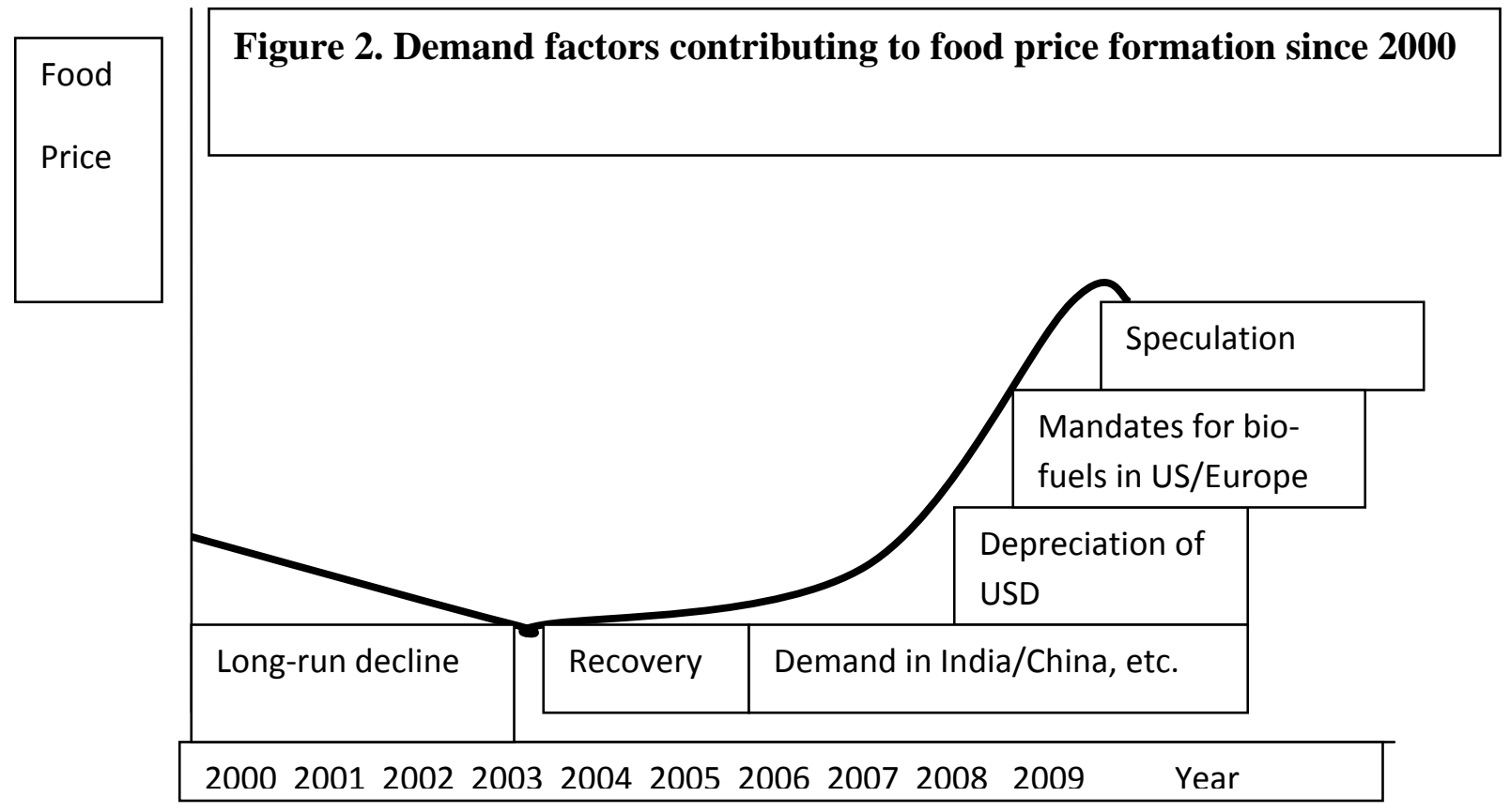

Source: Timmer, 2008a 


\section{The supply of storage model and short-run price behavior}

The link between the supply of grain held in storage and prices in both spot and futures markets has long been the subject of analytical attention (Working, 1933, 1948, 1949; Keynes, 1936; Kaldor, 1939; Telser, 1958, Brennen, 1958; Cootner, 1960, 1961; Weymar, 1968; Williams and Wright, 1991). The basic "supply of storage" model that has emerged from this theoretical and empirical work is the foundation for understanding short-run price behavior for storable commodities (Houthakker, 1987). It stresses the inter-related behavior of speculators and hedgers as they judge inventory levels in relation to use. The formation of price expectations is the key to this behavior.

\section{The basic supply of storage model}

The basic supply of storage model is a simple extension of the supply/demand model already used here. The formulation here follows Weymar's presentation, with three behavioral equations and one identity (error terms are omitted for simplicity):

$$
\begin{aligned}
& C_{t}=f_{c}\left(P_{t}, P_{t}^{L}\right) \\
& H_{t}=f_{h}\left(P_{t}, P_{t}^{L}\right) \\
& \left(P_{t}^{*}-P_{t}\right)=f_{p}\left(I_{t}\right) \\
& I_{t}=I_{t-1}+H_{t}-C_{t},
\end{aligned}
$$

Where $C$ = consumption, $P=$ price, $P^{L}=$ lagged price, $H=$ production (harvest), $I=$ inventory, and $P^{*}=$ expected price at some point in the future.

"The first two equations, indicating the dependency of consumption and production on current and/or lagged price, reflect traditional micro economic theory. While other variables may appear in these relationships (e.g. consumer income, government support levels), their exclusion here will not affect the discussion that follows. [The third equation] represents the "supply of storage" curve ... and reflects the notion that the amount of a commodity that people are willing to carry in inventory depends on their expectations as to future price behavior. If they feel that the price will increase substantially, they will be willing to carry heavier inventories (supply more storage) than would otherwise be the case. Because the inventory level is in fact determined by the identity expressed in [the fourth equation], the supply of storage function can be used to explain the gap between the current price and price expectations in terms of the current inventory level. [Weymar, 1968, p. 28]”

Thus the relationship between current inventories and current price helps explain price expectations, and vice versa. These price expectations can then be expressed in prices on futures markets. The actual working out of this theory empirically requires a close understanding of the behavior of market participants_-farmers, traders, processors, and end users (consumers) —in their role as hedgers or speculators. The current controversy over the role of "outside" 
speculators - investors who are not active participants in the commodity system - has many precursors in the history and analysis of commodity price formation on futures markets (see, for example, the Telser-Keynes debate reviewed by Cootner, 1960).

\section{The empirical relevance of the supply of storage model}

The empirical difficulty in using the supply of storage model to understand short-run price behavior is having current information on inventory levels. This is not such a severe problem when virtually all the commodity storage is in commercial hands, as with cocoa or wheat, and stock levels for such commodities are reported regularly or can be estimated fairly accurately. For a commodity such as rice, however, which is mostly grown by smallholders, is marketed by a dense network of small traders and processors, and is purchased by consumers in a readily storable form (milled rice), stock levels can change at any or all levels of the supply chain, and there are virtually no data available on these inventory levels.

For the purposes here, the main advantage of the supply of storage model is its ability to build conceptual links between long-run supply and demand trends, where basic models of producers and consumers provide operational guidelines to decision making and price formation, and very short-run movements in prices that often seem totally divorced from supply and demand fundamentals. Because long-run trends are gradually built up from short-run observations, these links are crucial for understanding price behavior even in the long run.

The key, then, to making the supply of storage model operational in the short run is to use it to gain insight on formation of price expectations. In the very short run, from day to day or week to week, these expectations seem to be driven by a combination of price behavior for commodities broadly and the specifics of individual commodities. Broad commodity price trends are captured by the IMF commodity price index, the Economist price index, or the Goldman-Sachs commodity price index, for example. Thus, traders operating in any one specific commodity market, such as oil, corn or wheat, will be following closely the broader price movements for all commodities (Sanders and Irwin, 2008). These broad price movements seem to be driven by basic macroeconomic forces such as rates of economic growth, the value of international currencies, especially the US dollar, and relative inflation rates (Timmer, 2008a).

But traders are also following closely the specifics of their commodity as well. Here inventories (especially relative to actual use for consumption) are the key to price formation, once the harvest/supply situation for the crop is established. Clearly, the analytics of price behavior for oil or metals begin to look quite different from the analytics of food commodities at this stage, as seasonal production and the inherent need to store the commodity for daily use throughout the year drive inventory behavior via the supply of storage.

Typically, commodities for which inventory data are reasonably reliable tend to have their shortrun prices driven by unexpected supply behavior, whereas commodities with poor data on inventories, especially where significant inventories can be in the hands of millions of small agents - farmers, traders, consumers - tend to have their extremes in price behavior generated by rapidly changing price expectations themselves, and consequent hoarding or dis-hoarding of the commodity. 
The short-run price dynamics for rice thus look significantly different from wheat or corn, partly because of the different industrial organization of the respective commodity systems. There are surprisingly few studies of individual commodity systems that are set within this broader macroeconomic and organizational framework (see Timmer, 1987, for an exception). The world food crisis in 2008 provides ample rationale for major new studies within this framework for all of the major food commodities.

These studies would generate considerable insight into why the short-run price dynamics for different commodities are so different, especially the varying roles of financial markets in accommodating, even driving, these price dynamics. However, long-run price relationships across commodities, and thus the dynamics of price trends over extended periods of time, are likely to be little influenced by the industrial organization of the commodity system and more influenced by changing relative technologies and tastes. These long-run relationships are analyzed in the final section of this paper.

\section{Why the difference in market structure for rice matters in short-run price formation}

Experience with world rice prices since the middle of the decade illustrates the importance of market structure to short-run price dynamics. The actual production/ consumption balance for rice has been relatively favorable since 2005, with rice stocks-to-use ratios improving slightly. This stock build-up was a rational response to the very low stocks seen at the middle of the decade and to gradually rising rice prices - exactly what the supply of storage model predicts. Short-run substitutions in both production and consumption between rice and other food commodities are limited, and until late 2007 it seemed that the rice market might "dodge the bullet" of price spikes seen in the wheat, corn and vegetable oil markets. The lack of a deeply traded futures market for rice also made financial speculation less attractive.

But the world rice market is very thin, trading just 7-8 percent of global production. While this is a significant improvement over the 4-5 percent traded in the 1960s and 1970s, it still leaves the global market subject to large price moves from relatively small quantity moves.

The global rice market is also relatively concentrated, with Thailand, Vietnam, India, the US and Pakistan routinely providing nearly $4 / 5$ of available supplies. Only in the US is rice not an important commodity from a consumer's perspective (although it certainly is for producers in the US). All Asian countries show understandable concern over access of their citizens to daily rice supplies. Both importing and exporting countries watch the world market carefully for signals about changing scarcity, while simultaneously trying to keep their domestic rice economy stable. These extensive policy concerns on the part of governments make rice a highly political commodity.

As concerns grew in 2007 that world food supplies were limited and prices for wheat, corn and vegetable oils were rising, several Asian countries reconsidered the wisdom of maintaining low domestic stocks for rice. ${ }^{14}$ The Philippines, in particular, tried to build up their stocks to protect against shortages going forward. Of course, if every country - or individual consumer - acts the

\footnotetext{
${ }^{14}$ What follows is a very brief overview of the "fire" in the world rice market from late 2007 until mid- 2008. See Slayton (2009) for a detailed analysis and chronology.
} 
same way, the hoarding causes a panic and extreme shortage in markets, leading to rapidly rising prices. Even US consumers are not immune from this panic, as the "run" on bags of rice at Costco and Sam's Club in April, 2008, indicated. Such price panics have been fairly common over the past 50 years, but the hope was that deeper markets, more open trading regimes, and wealthier consumers able to adjust more flexibly to price changes had made markets more stable. ${ }^{15}$ It turns out this was wishful thinking, as recent rice prices show.

After an acceleration started in October, 2007 in the gradual price increases seen for half a decade, concern over the impact of higher rice prices in exporting countries, especially India, Vietnam and Thailand, started to translate into talk, and then action (in India and Vietnam), on export controls. ${ }^{16}$ Importing countries, especially the Philippines, started to scramble for supplies. Fears of shortages spread and a cumulative price spiral started that fed on the fear itself.

The trigger for the panic was provided by inter-commodity price linkages. In India, the 2007 wheat harvest was damaged by drought and disease - as in so many other parts of the world. Thus the national food authority had less wheat for public distribution. Importing as much wheat as in 2006/07 (nearly $7 \mathrm{mmt}$ ) would be expensive (politically, if not necessarily economically) because of the high wheat price in world markets, so the food authority announced it needed to retain more rice from domestic production.

Barriers were put on rice exports in October-India is usually the second largest rice exporter in the world, $6 \mathrm{mmt}$ in 2007 (including over $5 \mathrm{mmt}$ of non-Basmati)--and eventually an outright ban on exports of non-Basmati rice from India was announced in April, 2008. Other rice exporting countries followed, as rice prices started to spike.

The newly elected government in Thailand did not want consumer prices for rice to go up, and the commerce minister openly discussed export restrictions from Thailand - the world's largest rice exporter, $9.5 \mathrm{mmt}$ in 2007. On March 28, 2008, rice prices in Thailand jumped \$75 per mt. Prices continued to skyrocket until it cost over $\$ 1100$ per mt in April - three times the price level prevailing at the beginning of 2008. This is the stuff of panics.

Low and declining rice stocks have been held accountable for the rising prices, with the argument that rice consumption has outpaced rice production for a number of years since 2000 (a mathematical inevitability if rice stocks are falling). Rice stocks in China have come down over the past decade, but that was a sensible response to growing reliance on trade as the buffer, and to lower prices in world markets. There has been little change in rice stocks in the rest of the world-indeed, the stocks-to-use ratio has been rising since 2005. Holding rice stocks in tropical conditions is extraordinarily expensive, so a smoother flow of rice internationally reduces this wasteful stockholding.

\footnotetext{
15 The prospect of more stable markets for rice from these forces was raised in Timmer, 1991.

${ }^{16}$ While to the casual observer, it is almost amusing that Indonesia announced a ban on rice exports early in 2008 , before its main rice harvest started in March. Historically, Indonesia has been the world's largest rice importer, surpassed only recently by the Philippines, and no one in the world rice trade was looking to Indonesia for export supplies. But there was a rationale to the announcement by the Minister of Trade-it signaled that Indonesia would not be needing imports and was thus not vulnerable to the skyrocketing prices in world markets. The calming effect of this announcement and other public relations efforts on domestic rice market participants meant that little of the hoarding behavior seen in Vietnam and the Philippines was evidenced in Indonesia.
} 
Now that the exporting countries are clearly willing to put bans on rice exports to protect their own consumers, nearly all countries will have increased incentives to resort to domestic stockpiles. That is a real tragedy for poor consumers and for economic growth—capital tied up in funding inventories is not very productive in stimulating productivity growth.

The psychology of hoarding behavior is important in explaining why rice prices suddenly shot up starting in late 2007. Financial speculation seems to have played only a small role (partly because futures markets for rice are so limited). Instead, decisions by millions of households, farmers, traders and some governments sparked a sudden surge in demand for rice and changed the gradual increase in rice prices from 2002 to 2007 into an explosion. This was "precautionary" demand even if not "speculative" demand, to use the language Keynes (1936) used in the debate over the role of speculative demand in the supply of storage.

A rough calculation of the effect of household hoarding of rice shows the potential. Assume that one billion households consume one kg of rice a day (for a total consumption of $365 \mathrm{mmt}$, for the year, which is the right magnitude).

Assume they keep a one-week supply in their pantry, or $7 \mathrm{~kg}$ per household, which is $7 \mathrm{mmt}$ of household stocks in total. This quantity probably varies by income class, with the very poor buying hand to mouth, and better off households storing more just for convenience. When prices start to rise, or the newspapers/TV start talking about shortages of rice, each household, acting independently, decides to double its own storage, thus buying an additional $7 \mathrm{~kg}$ per household. This means the world rice market needs to supply an additional $7 \mathrm{mmt}$ of rice over a short period (a few weeks...). This quantity is about one quarter of total annual international trade in rice (recent levels have been 27-30 mmt per year).

Roughly $7 \mathrm{mmt}$ is just the added demand from households. Farmers, traders, rice millers and even governments will also want to hold more stocks in these circumstances. As an example, the government of Malaysia announced that it was planning to more than triple the size of the national buffer stock held by BERNAS, even though it had to pay extremely high prices to do so (and the crisis ended before the new stock levels were achieved). The Philippines increased its government-held stocks. The Indonesian government set a target to triple its level of buffer stocks, from $1.0 \mathrm{mmt}$ to $3.0 \mathrm{mmt}$ (after which exports would be permitted).

To determine the impact on prices, short-run supply and demand parameters from the analytical model developed above can be inserted into the price determination mechanism: -0.1 for demand and 0.05 for supply. With a 25 percent increase in short-run demand on the world market (suddenly), the world price will have to rise by 167 percent to get a new equilibrium. That is what happened-panicked hoarding caused the rice price spike.

Fortunately, a speculative run based on herd psychology can be ended by "pricking the bubble" and deflating expectations. Once the price starts to drop, the psychology reverses on hoarding behavior by households, farmers, traders, and even governments. When the government of Japan announced in early June, after considerable international urging, that it would sell 300,000 tons of its surplus "WTO” rice stocks to the Philippines and others, prices in world rice markets started to fall immediately (Slayton and Timmer, 2008; Mallaby, 2008). By late August, medium 
quality rice for export from Vietnam was available for half what it sold for in late April, as dishoarding gained momentum. ${ }^{17}$

\footnotetext{
${ }^{17}$ As further evidence that psychology was driving prices in the world rice market rather than fundamentals, it was the announcement by the Prime Minister of Japan that rice supplies would be available to the Philippines and others, not their actual shipment, that pricked the price bubble and started the rapid decline in rice prices. As of mid-2009, Japan has actually not shipped any rice to the Philippines and overall rice exports declined in 2008 rather than increased as former Prime Minister Fukuda promised in Rome (Slayton, 2009).
} 


\section{Do Financial Markets Drive Price Formation on Commodity Markets?: Testing for Granger Causality across exchange rates and commodities ${ }^{18}$}

It is possible to examine the changing relationships for price formation across commodities in a formal way using the methodology of Granger Causality. Simply put, variable $X$ is said to "Granger Cause" variable $Y$ if time series information on variable $X$ adds to the explanation of variable $Y$ over and above the ability of past values of variable $Y$ to explain the current value. Econometrically, vector autoregressive (VAR) techniques are used to determine how much of variable $Y$ can be explained using just lagged values of variable $Y$ itself, after which lagged values of variable $X$ are added to the regression. If these lagged values are statistically significant in contributing additional explanatory power to variable $Y$, then variable $X$ is said to “Granger cause” variable $Y$. Reverse causation is routinely tested as well, and with many macro economic variables, direct and reverse causality are often found simultaneously. At this level, Granger Causality is purely a statistical relationship. In the context of a formal model of economic causation, however, Granger statistical results can provide powerful insights into causal arguments.

Most financial market analysts argue that the depreciating US dollar was a major reason for oil prices to rise. Through a bio-fuels connection, higher oil prices might then cause corn (maize) prices to rise (the main mechanism analyzed in the Farm Foundation report, see Abbot, Hurt and Tyner, 2008). Higher corn prices might then spill over to other commodities through both supply and demand linkages, thus causing wheat, rice, soybean or palm oil prices to rise. Using Granger causality methods, it is possible to test certain elements of these hypotheses. In the first instance we are seeking very short-run linkages that are most likely mediated through futures and other financial markets, so daily price movements are required to observe such short-run effects. Indeed, given the split-second decision making on most trading floors where these "investments" are being made, even daily prices might aggregate away some of the effects we wish to observe. $^{19}$

Figure 3 shows a startling result for the Granger test that the exchange rate between the Euro and the US dollar "causes" the price of oil (Brent). A 15-day lag is specified and the model is run on (daily) rolling 6-month horizons, starting on December 31, 1999 and ending on July 2, 2008. Each observation in Figure 3 is thus the outcome of a Granger regression on 6 months of daily price data, resulting in 2090 regressions. The vertical axis is the probability that the null

\footnotetext{
18 This part of the paper is very much research in progress and thus raises far more questions than it answers.

${ }^{19}$ Note that we are not attempting to test causality between participation in futures markets (for example, open "long” positions held by “non-trade” speculators) and consequent price behavior, the approach taken by Robles, Torero and von Braun (2009). Instead, we are looking for direct price links between a financial market and a commodity market, for example, between the U.S.-Euro exchange rate and the price of wheat or petroleum. The approach here avoids the need for data about participation in derivatives markets dealing in commodities, such as futures contracts on the Chicago Board of Trade. If over-the-counter trading in commodity swaps and options has been an important vehicle for new financial players, such as hedge funds and pension funds, to engage in commodity investments, this indirect approach is likely to provide better insight into the nature of linkages across markets.
} 
hypthosis of no Granger causation is rejected. Values between 0.95 and 1.00 reflect a very high probability that Granger causation in the direction specified is significant.

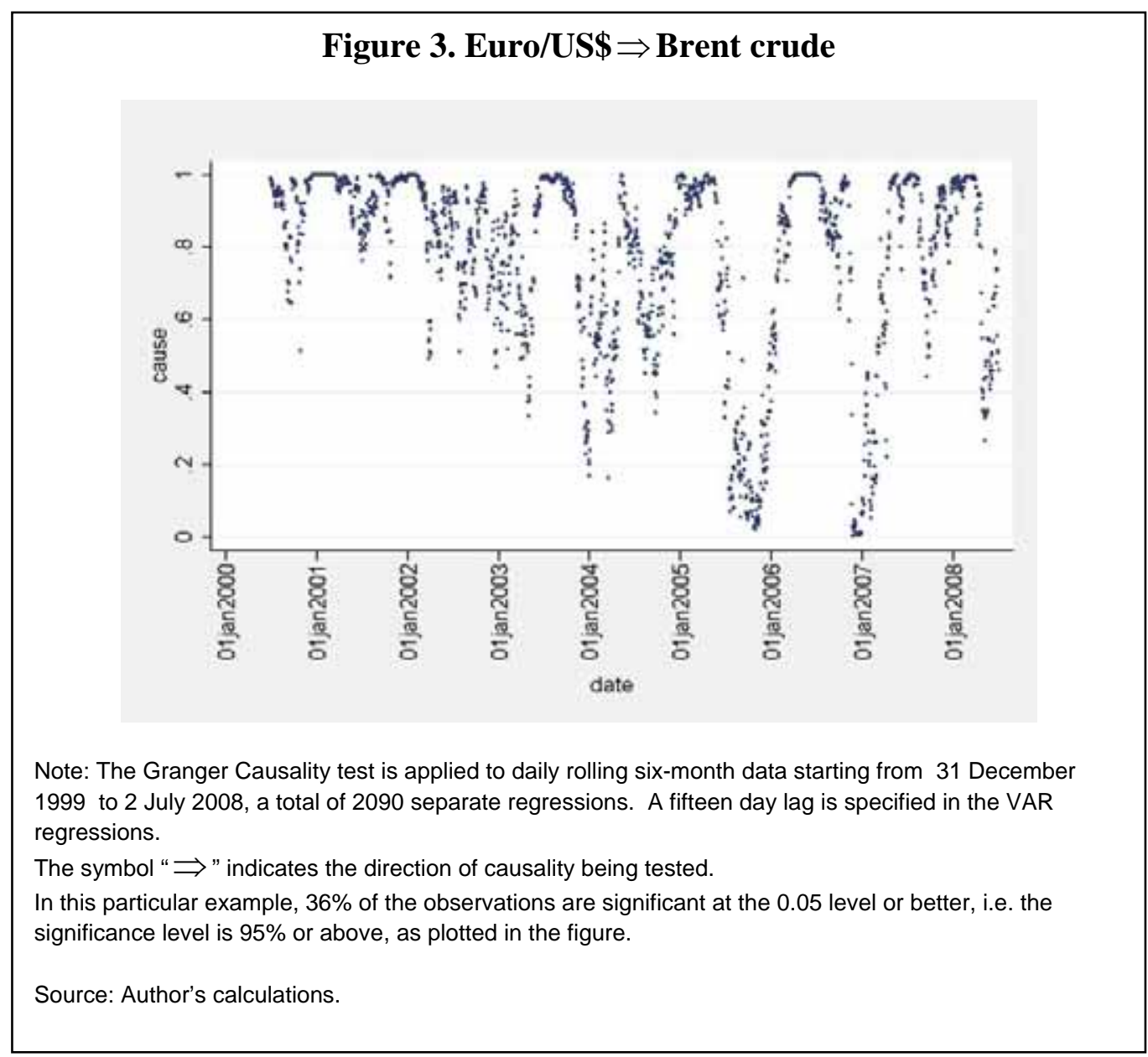

As Figure 3 demonstrates, there are several lengthy intervals when the exchange rate seems to be "causing" the price of oil—at least 7 intervals of more than two months just between 2000 and 2008. But there are also many intervals when there seem to be no linkages at all between the two markets. If the question is, "did the depreciation of the US dollar cause high oil prices," the answer seems to be, "it depends on when you look, but $36 \%$ of the time the answer is yes." No model that assumes a stable relationship between the two variables can possibly capture this behavior. To understand it, we almost certainly need to understand behavior in financial markets and especially the formation of price expectations on the part of traders in these markets, including markets for commodities.

Price expectations are hard to measure (much less forecast), but the supply of storage model tells us they are likely to be influenced most by volatile elements in both the supply and demand for the commodity. From this perspective, the most volatile element behind the sudden and sharp run-up in food commodity prices was likely to have been "hot money" in search of the next investment boom, after the crash in tech stocks and then real estate derivatives (and before the financial system itself crashed). The source of this hot money was the massive liquidity infusion provided by the US Federal Reserve System since at least the abrupt market correction after the 
9/11 attacks on the United States in 2001. This liquidity was no doubt a major contributor to the real estate bubble that reached its peak in 2006, but liquidity injections continued as the Fed sought to stave off (unsuccessfully, as it turns out) a recession caused by the collapse of these real estate values and subsequent threats to the nation's financial system (see Frankel, 2006).

This money had to go somewhere (as long as investors were still willing to take risks). Thus the real trigger for the spike in food prices in 2007 seems to have been speculative behavior on the part of large investment/ hedge funds with hundreds of billions of dollars looking for an arena with potential for asset price appreciation. The combination of a rapidly falling dollar, movement of investment funds into commodities, especially petroleum and then on to other commodities, was the trigger needed for commodity markets to explode. The Bank of International Settlements in Basel estimates that hundreds of billions of dollars were invested in commodity funds in late 2007 and early 2008, and until June, 2008, they all were betting on higher prices.

As noted already, rice prices in world markets did not follow these early price booms in oil, wheat and corn, mostly because the venues for speculation in rice price movements by "outside" investors in futures and options markets are extremely limited for rice. For example, average daily trading volumes in December, 2008 on the Chicago Board of Trade for corn and wheat futures contracts were 132 times the daily volume for (rough) rice. Daily volume for options contracts for corn and wheat were 557 times those for (rough) rice.

These tiny trading volumes mean it is not possible for major participants in world rice trade to routinely use futures and options markets to manage their price risks. ${ }^{20}$ In reverse, "outside” speculators have very limited instruments to participate in or drive movements in rice prices. Still, formation of rice prices can be significantly influenced, especially in the short run, by price behavior in other related commodity markets because prices in these other markets influence how the millions of small-scale participants in the rice system form their own expectations about rice prices. As was seen in late 2007 and early 2008, these expectations can be self-fulfilling.

Of course, the depreciating dollar does not need to act through oil prices alone to affect commodity prices; it can also directly impact these prices. In the medium run, both supply and demand adjustments by producers and consumers to changes in the value of the US dollar relative to their own domestic currency cause the US dollar price of most commodities to rise when the dollar falls. These price changes can be explained by the "fundamentals" of supply and demand.

In the very short run, however, in daily price formation, a declining dollar seems likely to stimulate financial speculation in commodity markets, thus establishing a direct price link even before producers and consumers have had a chance to adjust. These short run price linkages are important even for rice (see Figure 4). For long periods of time the Euro/US\$ rate seems to drive the price of Thai rice. This may simply be a factor of the Thai Baht being linked to the

\footnotetext{
${ }^{20}$ A further reason traders in the world rice market do not use the (rough) rice contract on the Chicago Board of Trade to hedge their price risk is that there is surprisingly little correlation between U.S. rice prices and rice prices quoted in Asian markets (Dawe, 2008d). Between 1996 and 2006, for example, the average R squared for a regression on changes in US export prices and Thai export prices for rice was just 0.012 . Traders would face the prospect of significant basis changes if they used US rice futures contracts to hedge prices of Asian rice.
} 
appreciation of the Euro, with the US dollar price of Thai rice being converted directly from the Baht wholesale price. $^{21}$

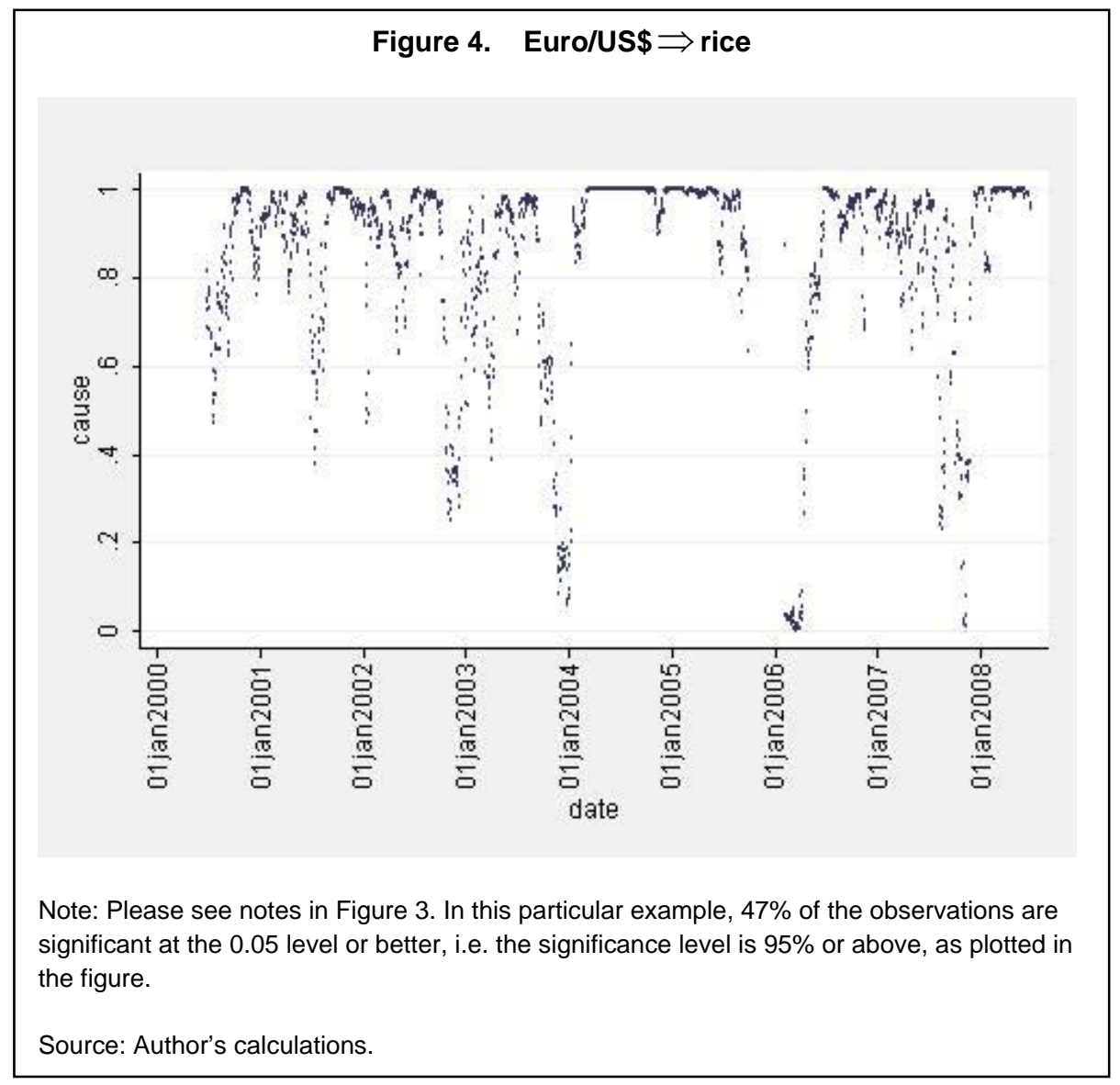

Rice price behavior is also unusual in terms of cross commodity linkages. Normally, rice behaves as a "special" commodity, driven mostly by national and international balances for the commodity itself, with relatively weak connections to other commodities (Dawe, 2008a,b,c). Rice is not typically used for livestock feed or bio-fuel production, except in very unusual circumstances. The Japanese, for example, allow their imported rice required by WTO commitments to deteriorate in storage, and then feed it to livestock.

But there are substantial regions in Asia where rice competes with wheat in consumption. Over the long run, commodity analysts expect rice and wheat prices to reflect this substitution and exhibit a relationship that captures the opportunity cost of producing each commodity (at the long-run margin). Although this relationship is likely to be stable only in the long run, with very

\footnotetext{
${ }^{21}$ The "daily" rice price used in this analysis is Thai 5\% brokens, FOB Bangkok. The official source for this price, the Thai Board of Trade, only issues it on a weekly basis, and even then the official price quotes are often significantly different from the prices at which actual trades are taking place. One simple indicator of how "different" the world rice market is from the corn and wheat markets is that there is no daily, transparent, reliable price quotation for rice exports from any of the major origins.
} 
substantial divergences from year to year, it is apparently important enough for short-run commodity traders to factor wheat prices into expectations about rice prices, and vice versa. Figures 5 and 6, respectively, show the episodes when short-run prices of hard wheat drive rice prices, and when rice prices are driving the prices of hard wheat.

Although the timing of these linkages across the commodities is not yet understood, it is clear that financial markets must be the main integrator of these markets in the very short run, for daily price formation. The Granger Causality results show that there are episodes when the rice market is connected to the hard wheat market (in both directions). The wheat market (mostly via the market for soft wheat, which competes at both the production and consumption margin with hard wheat) is connected to the maize market. And all of these commodity markets are linked at times to the market for oil and to the rate of exchange between the Euro and the US dollar. ${ }^{22}$

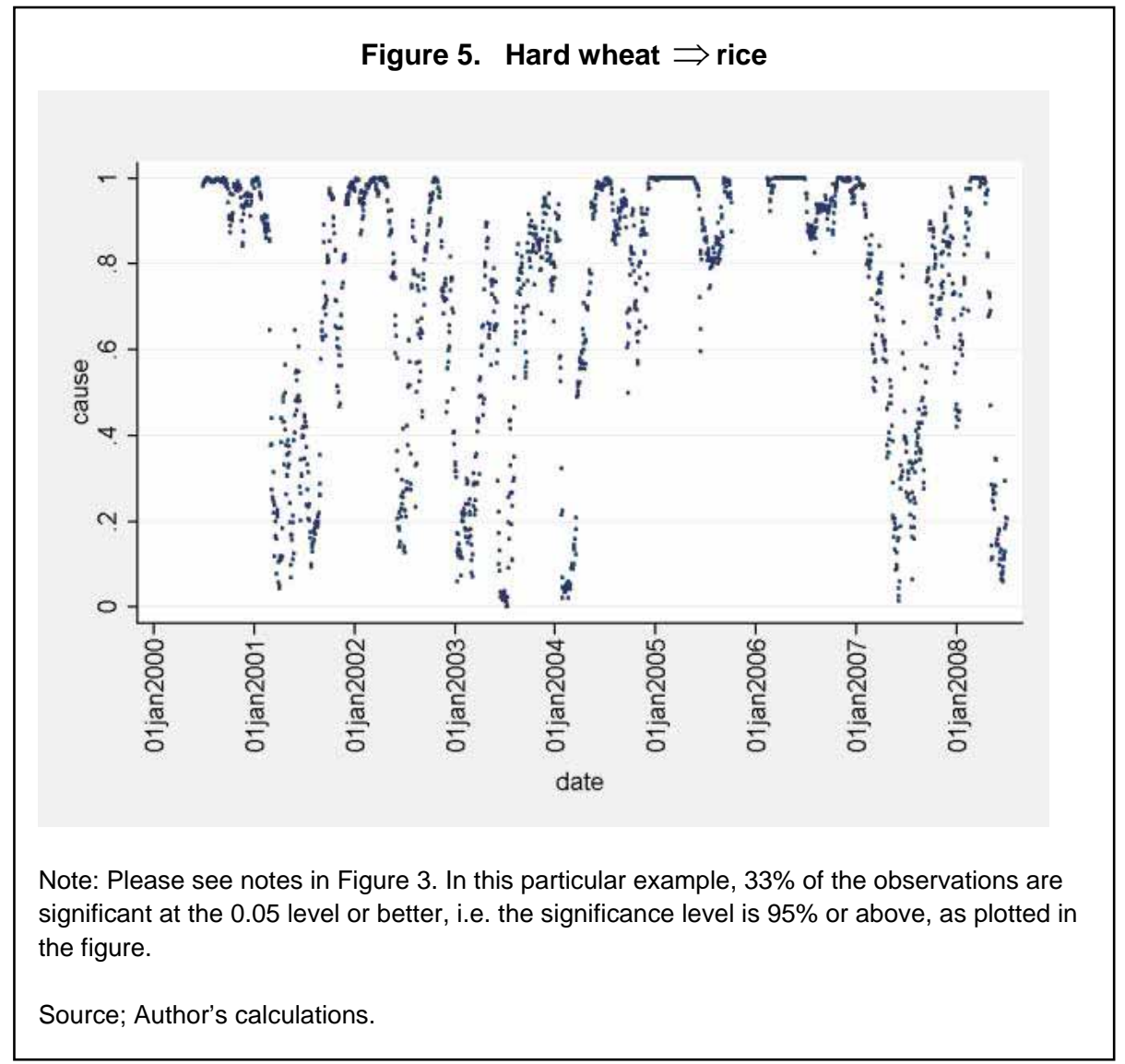

\footnotetext{
${ }^{22}$ See Appendix 1 for analysis of causal linkages from exchange rates to the prices of corn and wheat, which also come and go over time. Appendix 2 then extends the analysis to cross-commodity price linkages.
} 


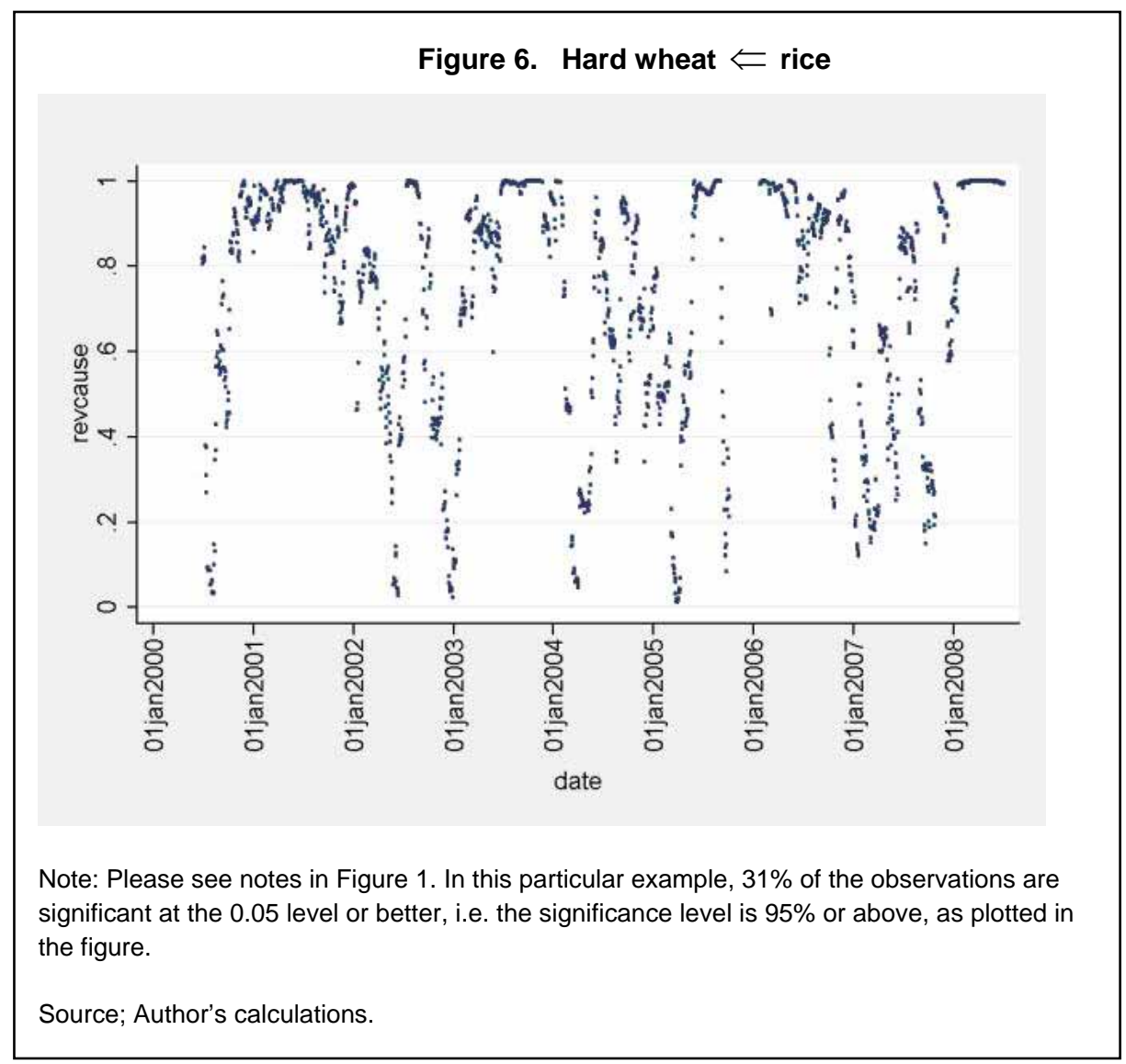




\section{Long-run price relationships among the staple cereals}

As noted, most commodity market analysts think there is a long-run relationship among the prices of staple grains, based on commodity substitutions in both production and consumption (Timmer, Falcon and Pearson, 1983). Mitchell (2008), for example, argues that wheat prices historically have averaged about 60-80 percent of the price of rice (and thus were far "too high" in early 2007, reflecting speculative pressures in the wheat market). Table 2 presents results from analyzing the long-run relationship between prices of the three basic cereal staples, rice, wheat and corn (maize), since 1900.

It is clear there has been a long-run decline in the prices of all three cereals - there is a basic commonality in this decline, as all three commodities have trend price declines of more than 1.0 percent per year. Further, this decline accelerated after the mid-1980s, again for apparently common reasons (see Figures 7, 8 and 9). Even the recent run-up in cereal prices in 2007-08 barely returned them to the long-run downward trend. From the figures it is clear that, relative to these trends, wheat and maize prices rose more sharply than did rice prices. It is also clear from the table and figures that price formation for rice has several unique dimensions that are worthy of further study.

Two basic models of long-run price formation are tested in Table 2 for each of the three basic food cereals, rice, wheat and maize. The first asks simply what the long-run time trend in real prices is, without further explanatory variables (Equations 1, 3 and 5). There can be no mistaking the sharp downward trend, either econometrically in Table 2 or visually from Figures 7, 8 and 9 (where the fitted trends are shown against the raw data). The trend decline for rice is 1.34 percent per year, for maize it is 1.25 percent per year, and for wheat it is 1.05 percent per year. The difference between the trend decline for rice and wheat is significant at the 5 percent level. Something has been driving rice prices down faster than wheat prices over the past century. The difference between the simple trend decline for rice and maize is not significant. The very simplicity of this trend analysis, of course, precludes any attempt at explaining why there are differences in trends.

The second model is slightly more sophisticated and starts to address the issue of differences in price formation among the three cereals (Equations 2, 4 and 6). This model still tests for the existence of a time trend, but now the trend estimate for the price of each commodity is (statistically) controlled for the prices of the other two commodities in the same year. ${ }^{23}$ The results are actually quite dramatic. The downward time trend for wheat disappears altogether, with rice prices (coefficient $=0.19$ ) and maize prices (coefficient $=0.59$ ) both having a highly significant impact on wheat prices.

Maize prices behave in a similar but less dramatic fashion. The time trend is only -0.27 percent per year, although it is statistically significant. Rice prices have only a marginal impact on maize prices, with a coefficient of 0.13 which is not significant at the 5 percent level. Wheat prices,

\footnotetext{
${ }^{23}$ Technically this assumes that the prices are independent of each other in the same year, which is obviously not true if their price formation is determined simultaneously from a common set of exogenous factors. This not a serious problem here, where the issue is simply the impact of the other commodity prices on the "exogenous" time trend. Introducing lagged values would solve the econometric problem without changing the results discussed here.
} 
however, have a very large impact on long-run maize prices (confirming the short-run results seen in the Granger Causality tests), with a coefficient of 0.77 that is highly significant.

Although somewhat related to wheat and maize prices, rice prices clearly have a different pattern of price formation. The impact of maize prices on rice prices is only marginally significant (as was the case in reverse). Wheat prices have a modest impact which is statistically significant. Comparing the sum of the two coefficients for each of the three regressions is revealing: the sum for rice (of the maize and wheat coefficients) is 0.73 , with an average $t$-statistic of only 2.6. The total for wheat (of the rice and maize coefficients) is 0.78 , with an average $t$-statistic of 6.3.

Maize prices are best explained by the other two commodity prices: the sum of the coefficients is 0.90 , with an average $t$-statistic of 5.6. Clearly, rice prices exhibit substantial independence from maize and wheat prices. This conclusion is also borne out by the adjusted R-squared coefficients for each of the price regressions: rice is "only" 0.77 whereas both maize and wheat are 0.86 . There is more unexplained variance in the price of rice over the long run, a measure of its greater volatility.

Most significantly, the exogenous time trend for real rice prices, even after controlling for the impact of wheat and maize prices, continues to be substantial and negative, with a significant coefficient of -0.53 percent per year. Even if maize and wheat prices remained stable in real terms, rice prices would be lower by more than 40 percent after a century.

There would seem to be two implications of these statistical results. First, both maize, and especially rice, prices, have been driven down by powerful exogenous factors, even after controlling for the general decline in the prices of the other grains. Presumably differential technological change is the main driver of these negative time trends, although demand growth for rice may have been slower over the long run than for wheat. Because of its role in livestock feeding, however, the demand for maize has grown the fastest of the three cereals, yet it still has a small but significant downward trend in price, after allowing for the general decline in cereal prices. This pattern suggests that differential technological change is probably the main driver of prices over the long run.

Second, rice prices clearly have a life of their own. This is seen in the strong downward time trend when tested alone, in the continued significance of a downward trend when allowance is made for the prices of wheat and maize, and for the relatively small explanatory power of the fully specified price model that allows for these other prices. What causes these long-run differences in price trends?

For the short run, the answer would seem to lie in market structure. It has already been established here that one unique dimension of short-run rice price formation stems from the highly unusual industrial organization of the world's rice economy, with many small producers, traders, retailers and consumers handling a product that is storable at each stage.

The supply of storage model, in turn, argues that this highly decentralized storage capacity is subject to changes in price expectations on the part of participants all along the supply chain. These expectations become self-fulfilling and lead to episodes of panic buying, and subsequent de-stocking, which sharply destabilize actual prices. Because no one has data on size of rice stocks in the hands of these multitudinous market participants, their impact on rice price 
formation is virtually impossible to predict ahead of time. Rice really is "different" in the short run.

Does this difference in market structure also account for the difference in long-run price trends between rice and the other two staple food grains, corn and wheat? Only to a limited extent. The faster downward trend in rice prices, even holding constant the prices of wheat and corn, argues that the long-run equilibrium between supply and demand for rice is shifting down faster than for corn and wheat. Faster technological change for rice could push the supply curve out faster. Slower population growth in rice-consuming countries, and a faster transition to very low, even negative Engel Coefficients for rice, could account for slower demand growth. Changing consumer tastes could also be a factor.

But the greater variance in the downward trend for rice (the lower R-squared) does suggest that market structure has long-run significance as well as short-run significance. The political economy of high variance in world rice prices is well understood-it leads countries to retreat into autarky, and dump their own instability into a smaller world rice market. One consequence of this drive for self-sufficiency among rice importers is larger overall production than would be expected in a world of free trade. This added production should also contribute to a long-run decline in world prices. 
Table 2. Long-run relationships among rice, wheat and maize prices, 1900-2008

Dependent Variable: Logarithm of price of...

Rice Wheat Maize

$\begin{array}{lllllll}\text { Equation } & 1 & 2 & 3 & 4 & 5 & 6\end{array}$

Number

Independent

Variables

\begin{tabular}{|l|l|l|l|l|l|l|}
\hline Constant & 31.5944 & 11.5888 & 26.0225 & 2.2670 & 29.9852 & 5.8011 \\
\hline (t-stat) & $(16.7)$ & $(3.9)$ & $(16.5)$ & $(1.1)$ & $(17.2)$ & $(2.6)$ \\
\hline Time ${ }^{24}$ & -0.0134 & -0.0053 & -0.0105 & -0.0005 & -0.0125 & -0.0027 \\
\hline (t-stat) & $(14.1)$ & $(4.0)$ & $(13.0)$ & $(0.6)$ & $(14.1)$ & $(2.7)$ \\
\hline LRice & -- & -- & -- & 0.1910 & -- & 0.1345 \\
\hline (t-stat) & & & & -- & -- & $(1.9)$ \\
\hline LWheat & -- & 0.4728 & $-2)$ & & 0.7661 \\
\hline (t-stat) & & $(3.2)$ & & -- & & \\
\hline LMaize & -- & 0.2569 & -- & 0.5909 & -- & \\
\hline (t-stat) & & $(1.9)$ & & $(9.3)$ & & \\
\hline Adj. R sq & 0.645 & 0.771 & 0.609 & 0.857 & 0.645 & \\
\hline
\end{tabular}

Source: Data from Eberstadt (2008), analysis by author.

${ }^{24}$ Because the price terms are in logarithms, the coefficient on the time variable can be interpreted as the annual percent "trend" change in the dependent variable. Thus, in Equation 1, the annual rate of decrease in rice prices is estimated to be 1.34 percent per year, before allowance is made for the impact of price changes for other staple food commodities. Holding constant the prices of wheat and maize in each year, the trend decrease in rice prices drops to just 0.53 percent per year. A similar interpretation holds for the time coefficients for the other commodities. 


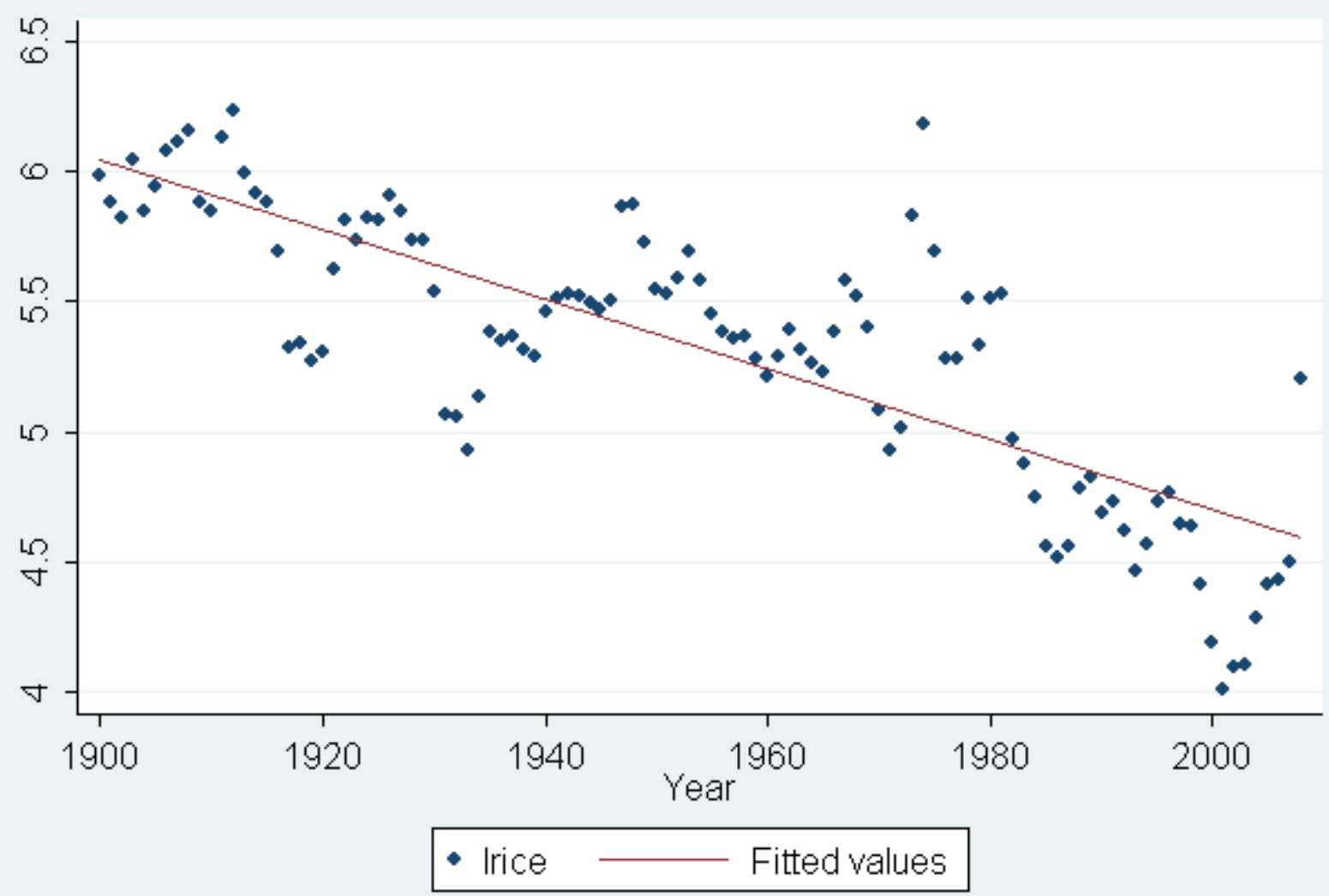

Irice year

Figure 7. Long-run trend in real rice prices, 1900-2008

Source: Data from Eberstadt (2008), analysis by author. 


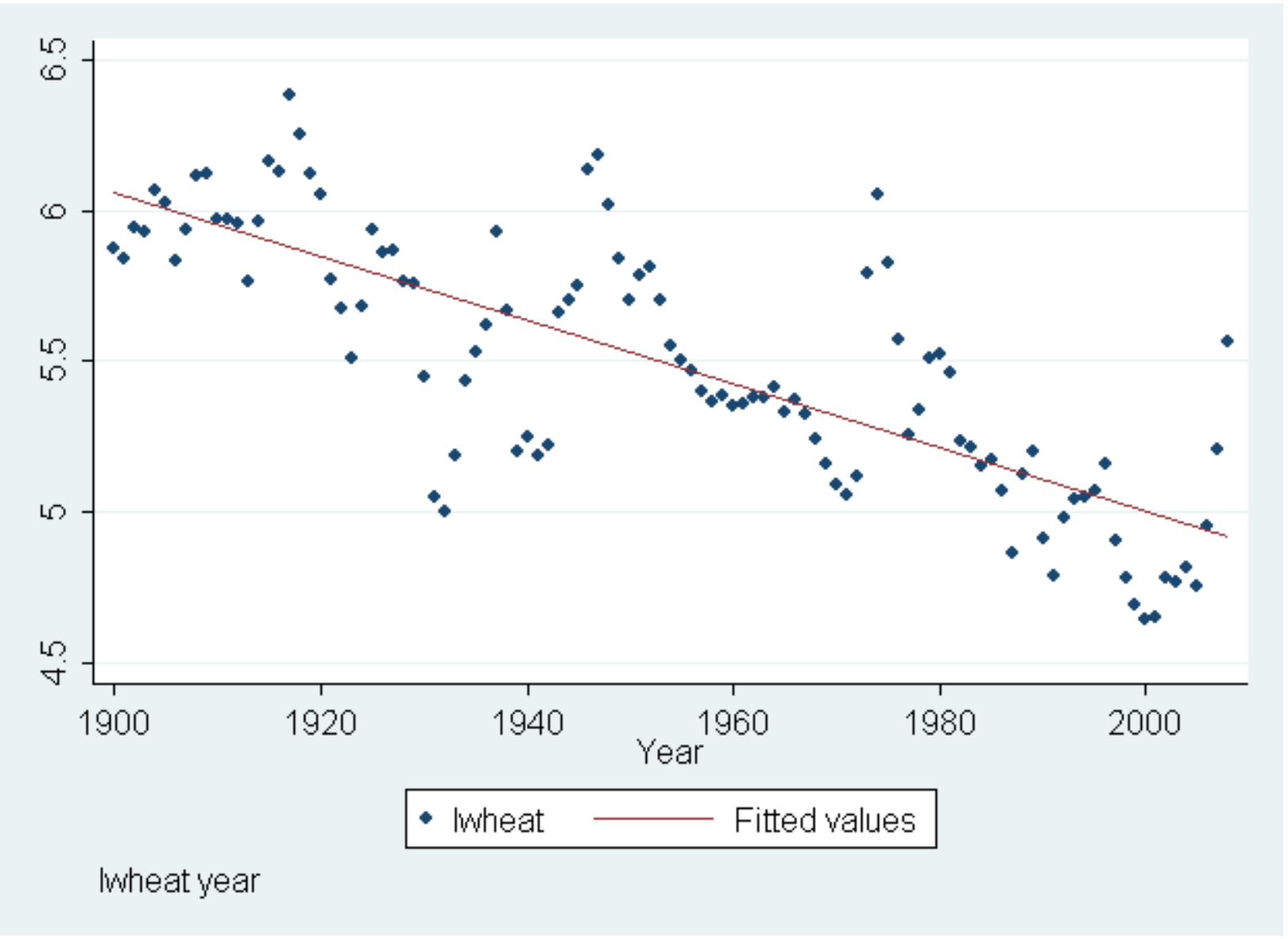

Figure 8. Long-run trend in real wheat price, 1900-2008

Source: Data from Eberstadt (2008), analysis by author. 


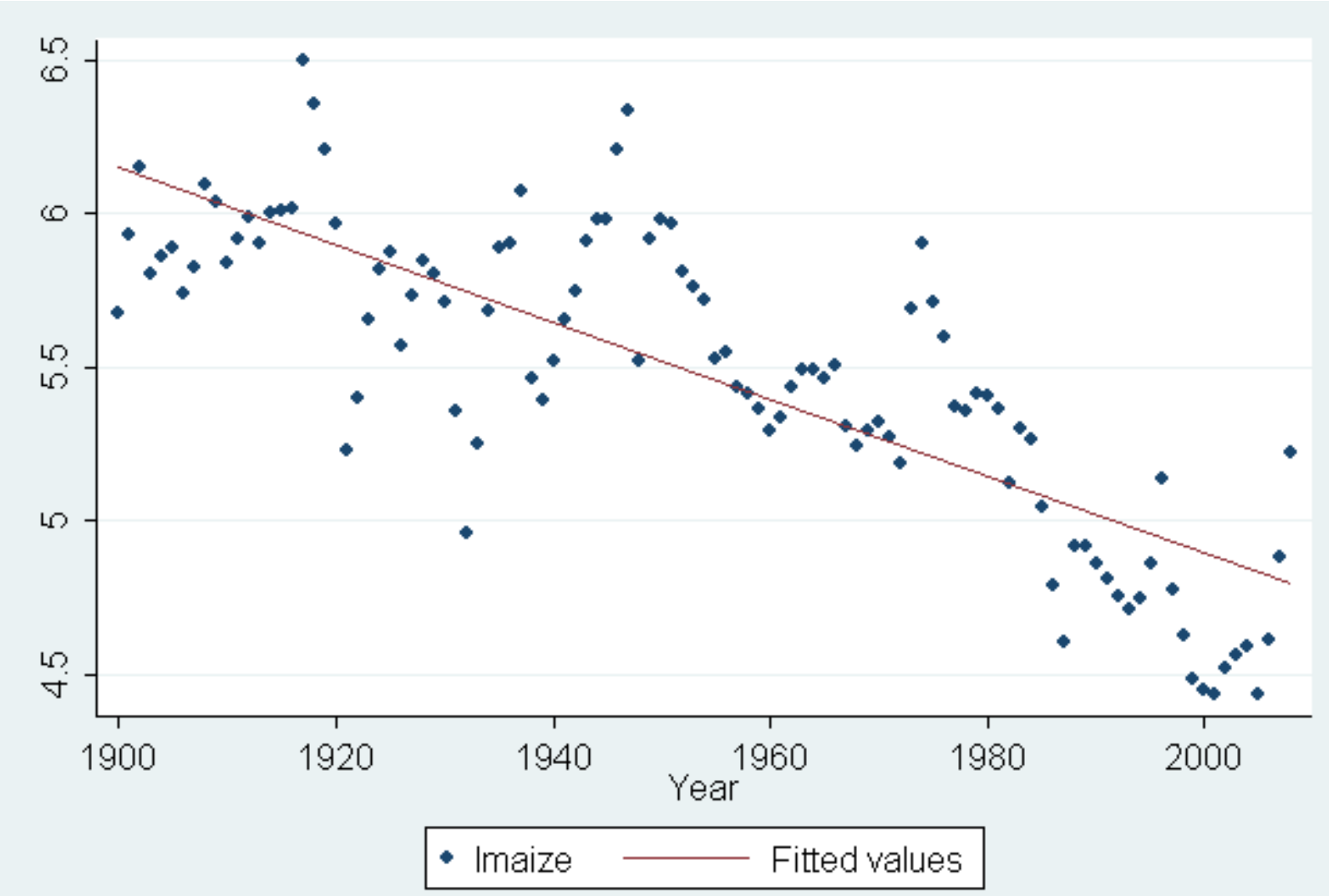

Imaize year

Figure 9. Long-run trends in real maize prices, 1900-2008

Source: Data from Eberstadt (2008), analysis by author 


\section{Conclusions and Observations on Stabilizing Rice Prices}

It has taken a lengthy sequence of analytical and empirical steps to understand both the short-run and long-run formation of rice prices. But it is now possible to revisit the four questions asked at the beginning of this paper about the role of "destabilizing" speculation in the rice price spikes seen in late 2007 and early 2008: how much, through what mechanisms, what happens as these influences unwind, and how is the story for rice different from other commodities? A final question also seems relevant at this stage: can anything be done about unstable rice prices?

On the basis of the evidence presented in this paper, it is possible to answer these questions through a sequence of six steps: ${ }^{.5}$

(1) in the long run, the commodity markets for rice, wheat and corn are similar in that they are influenced by basic supply and demand factors, although the long-run decline in rice prices has been faster than for wheat and corn;

(2) these commodity markets (and others) are connected by financial markets, even in the very short run, before basic adjustments in supply and demand are possible;

(3) wheat and corn (with more interchangeable uses, especially in livestock feeding) are more closely connected with each other than with rice markets. Any impact of bio-fuels in the price spikes would have been mediated through the corn market and its financial linkages to other commodity markets;

(4) in the short run, some of the run-up in wheat and corn prices was almost certainly caused by financial speculators, who were fueled by high liquidity, flight from collapsing real estate markets, and a conviction that higher oil prices also meant higher food prices;

(5) but rice speculation, because of the different industrial organization in both domestic and international rice markets (and the active intervention by many governments), was mostly the result of hoarding by small traders and consumers, not financial speculation from outside investors. This hoarding was a "rational" behavioral response by millions of individuals to the actions of panicky governments and the consequent impact on prices. Talk of a price spiral induced a real price spiral;

(6) finally, the unwinding of speculative positions leads to rapid price declines, until the perceived surplus stocks are consumed. With the exception of India, this process of short-run destocking seems to have ended in late 2008, well before world prices had returned to their rising trend from 2002 to 2007. The world financial crisis will probably keep rice prices from rising rapidly again, but the supply/demand balance for the next few years suggests export prices will be closer to $\$ 500$ per ton rather than the $\$ 300$ per ton seen in the pre-crisis period. ${ }^{26}$

\footnotetext{
${ }^{25}$ I am indebted to Ralph Cummings for suggesting this sequence approach.

${ }^{26}$ Admittedly, there is no clear justification from the analytics or empirics presented in this paper for these projected prices for rice. Rather, it derives from a personal weighing of the market trends and changes in their underlying causal factors.
} 
These conclusions are reached mostly by eliminating the other explanations and by logical reasoning. There is no specific quantitative test of the hypothesis on offer, and indeed, one may not be possible.

It is difficult to judge who gained and who lost in this latest episode of rice price volatility. Certainly, poor consumers in Viet Nam and the Philippines lost, as did consumers in many other rice importing countries, especially in Africa. Some large countries kept the rice shock from their domestic farmers and consumers - India (which banned exports of non-basmati rice), China (which sharply restricted rice exports in late 2007 and early 2008), and Indonesia (which banned rice exports, despite its traditional role as a rice importer) all kept domestic rice prices fairly stable by withdrawing from trade. Political leaders in these countries argued that domestic stability was more important than international stability. ${ }^{27}$ These arguments reflected a longstanding perspective in Asia that rice price stability is essential for both political stability and economic growth (Timmer and Dawe, 2007).

But this is a vicious circle. Instability on world markets causes politicians to withdraw their countries from importing and exporting rice. The thinner market becomes even more unstable, causing even more ad hoc policy reactions. This is not a new story. Trade restrictions played a key role in causing the world food crisis in 1973/74 (Falcon and Timmer, 1974). Newbery and Stiglitz (1981) established nearly three decades ago the dynamics of instability in world commodity markets, and the tension between domestic and international price stability became an object of intense discussion about the sharp fall in commodity prices in the mid-1980s (Deaton and Laroque, 1992; Salant, 1983: Timmer, 1989, 1991, 1996, 2000).

Breaking into this vicious circle, seen clearly in the price spike in late 2007 and early 2008, seems likely to require binding agreements, perhaps even contracts, between rice importers and exporters over multi-year periods, not just for short-run trade, as a way to rebuild confidence in the world market. Because there seem to be virtually no national or international pressures for such binding agreements, rice is likely to remain a very different, and political, commodity for decades to come. ${ }^{28}$

\footnotetext{
${ }^{27}$ The overwhelming victory by the Congress Party in India in May, 2009 gives credence to these political arguments.

${ }^{28}$ One way forward might be for an ASEAN-led initiative to create a free trade zone for rice in the region. If such a zone included south China, Bangladesh and India, most of the world's rice producers and consumers would be exposed to more stable prices, and the entire world rice market would be more stable as well. Perhaps Indonesia, with its new-found self-sufficiency in rice, could host discussions on such an initiative.
} 


\section{Appendix 1. Exchange rates driving food commodity prices}

Figures A1-1 and A1-2 show how connections established by Granger Causality come and go between the Euro/US\$ rate and corn (maize) and hard wheat prices respectively. We still do not know why these short-run speculative connections get established for shorter or longer periods of time, and then disappear altogether for extended periods of time.

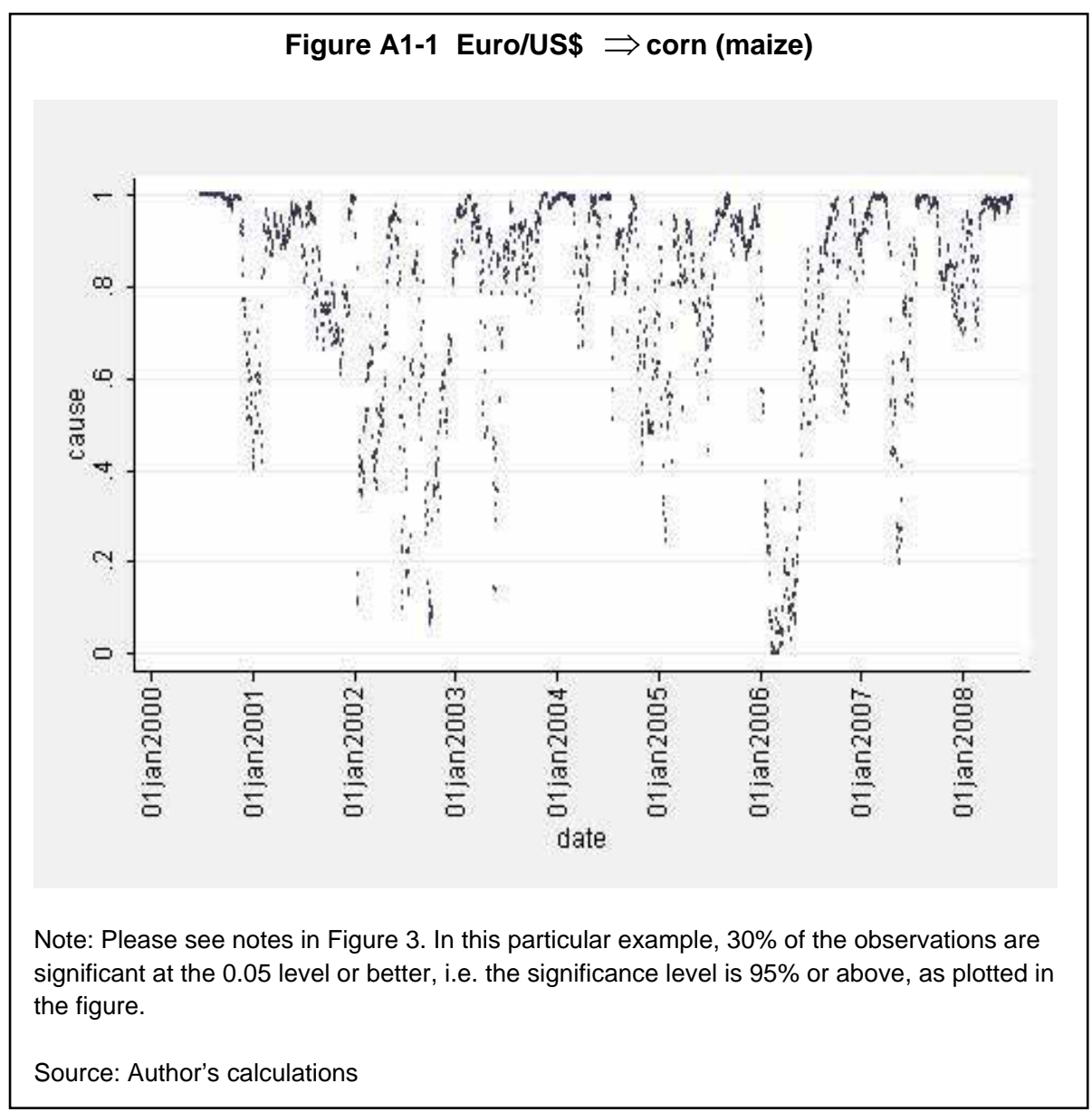




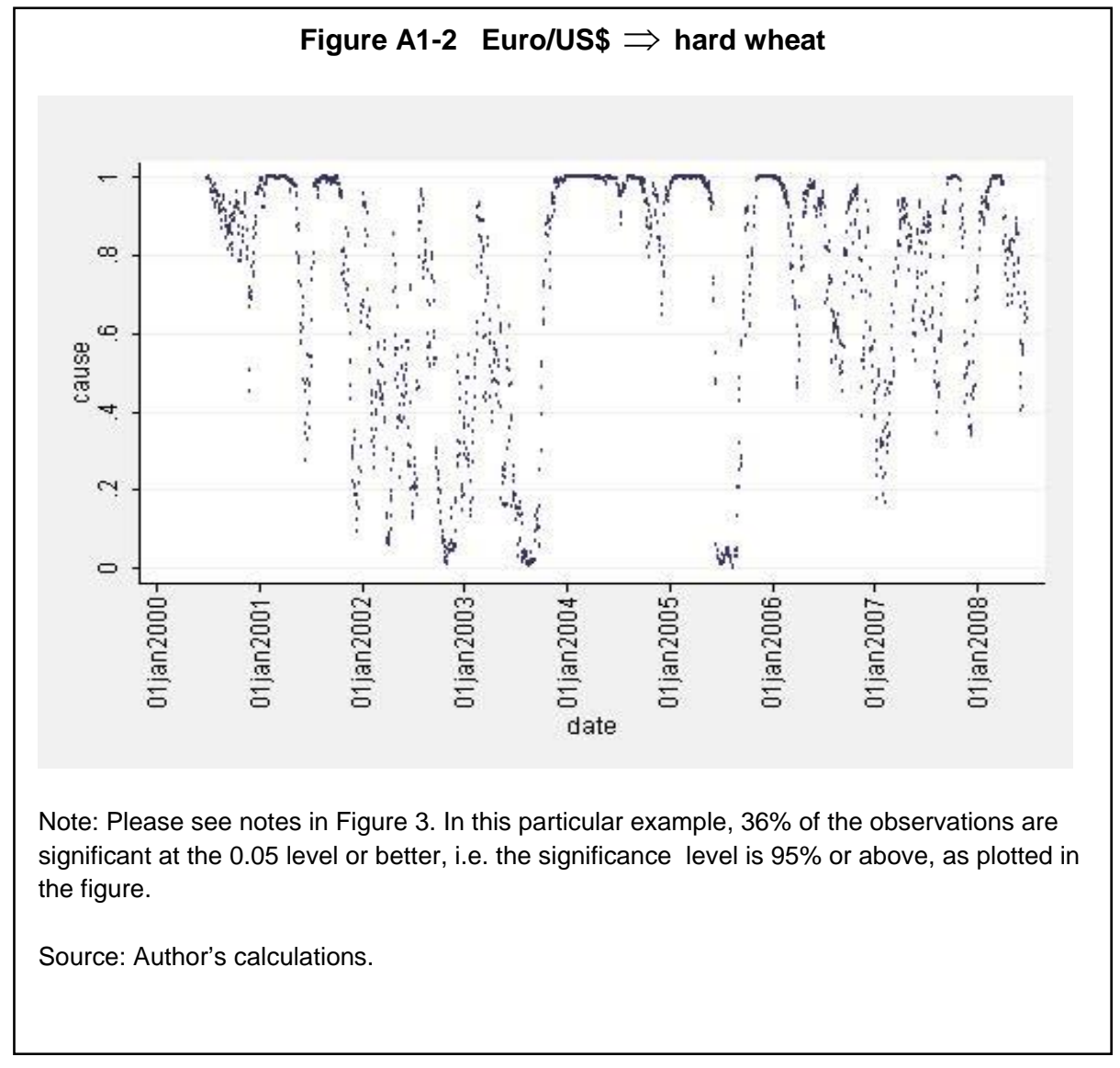




\section{Appendix 2. Cross-commodity linkages}

One broad hypothesis underlying the various explanations for sharply higher food prices on world markets has been the link between oil prices and food commodity prices. As Timmer (2008a) puts it, if high oil prices are here to stay, high food prices are here to stay. The logic of this connection, through bio-fuel production, depends on medium- to long-run responses by producers and consumers to the profitability of converting corn or vegetable oils into ethanol or bio-diesel. ${ }^{29}$ But again, financial speculators can see this longer-run potential and convert it into short-run price behavior by investing in futures markets (and other more exotic derivatives). Figures A2-1 and A2-2 show how the oil price drives the daily formation of maize and palm oil prices. Again, we need to understand why the periods of strong price linkages come and go.

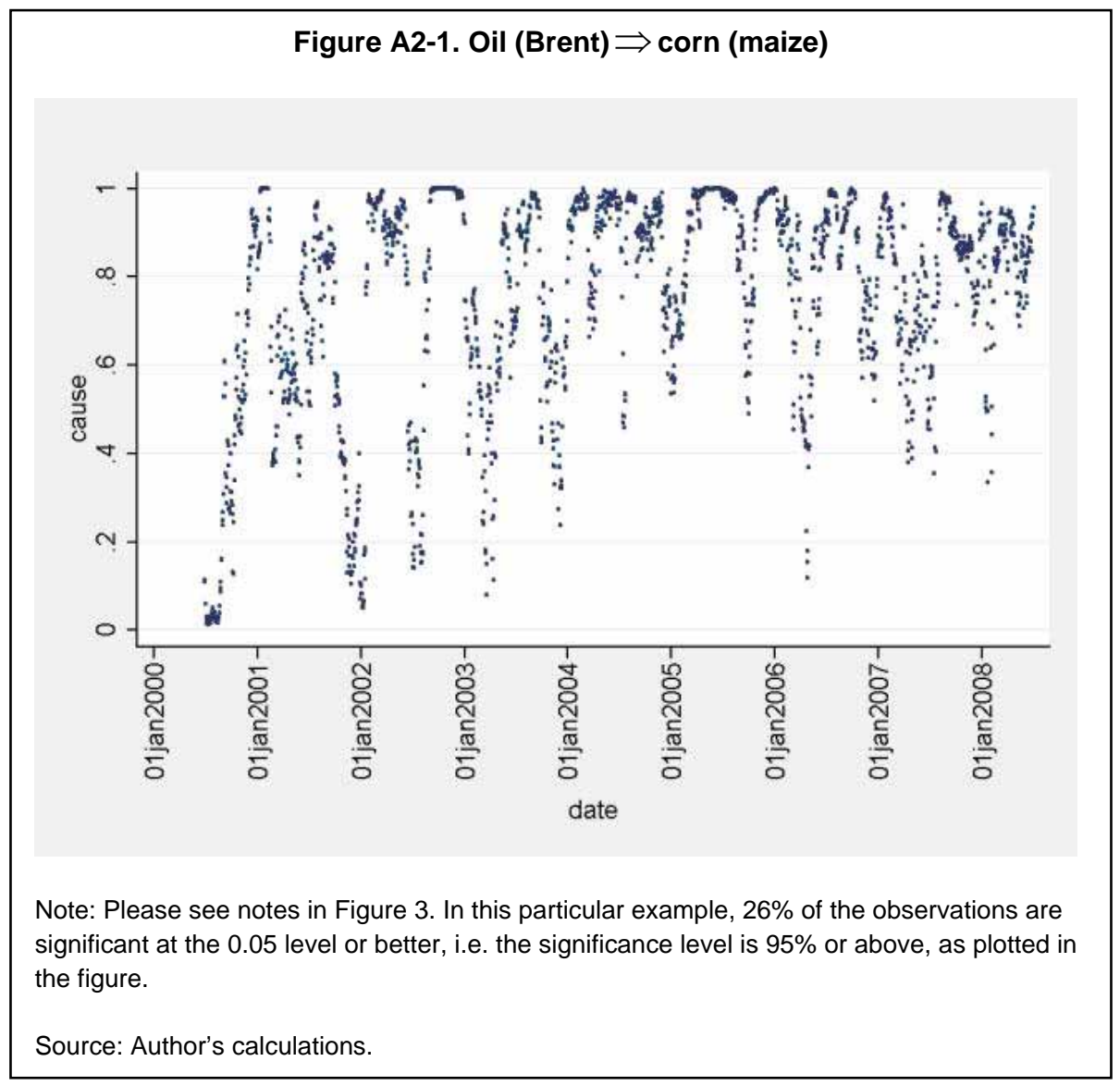

Most commodity analysts think the main connection between the maize market and wheat market comes through livestock feeding, with soft wheat serving as a very close substitute for maize in many feed rations. Figures A2-3 and A2-4 test in which direction this linkage tends to run in the very short run. Visually, it seems like soft wheat had more of an impact on maize prices before 2004 (Figure A2-3), with maize having more of an impact on soft wheat after then

\footnotetext{
${ }^{29}$ There has been a long-standing link between energy prices and the price of food commodities because of links from the supply side-irrigation costs, fertilizer costs, cultivation costs, transportation costs and processing costs all are significantly influenced by energy costs (Timmer, 1984).
} 
(Figure A2-4). Such a change would be consistent with the argument that bio-fuel demand for maize in the US after 2005 became a much more important driver of maize prices. Formal confirmation of this hypothesis is part of the on-going research.

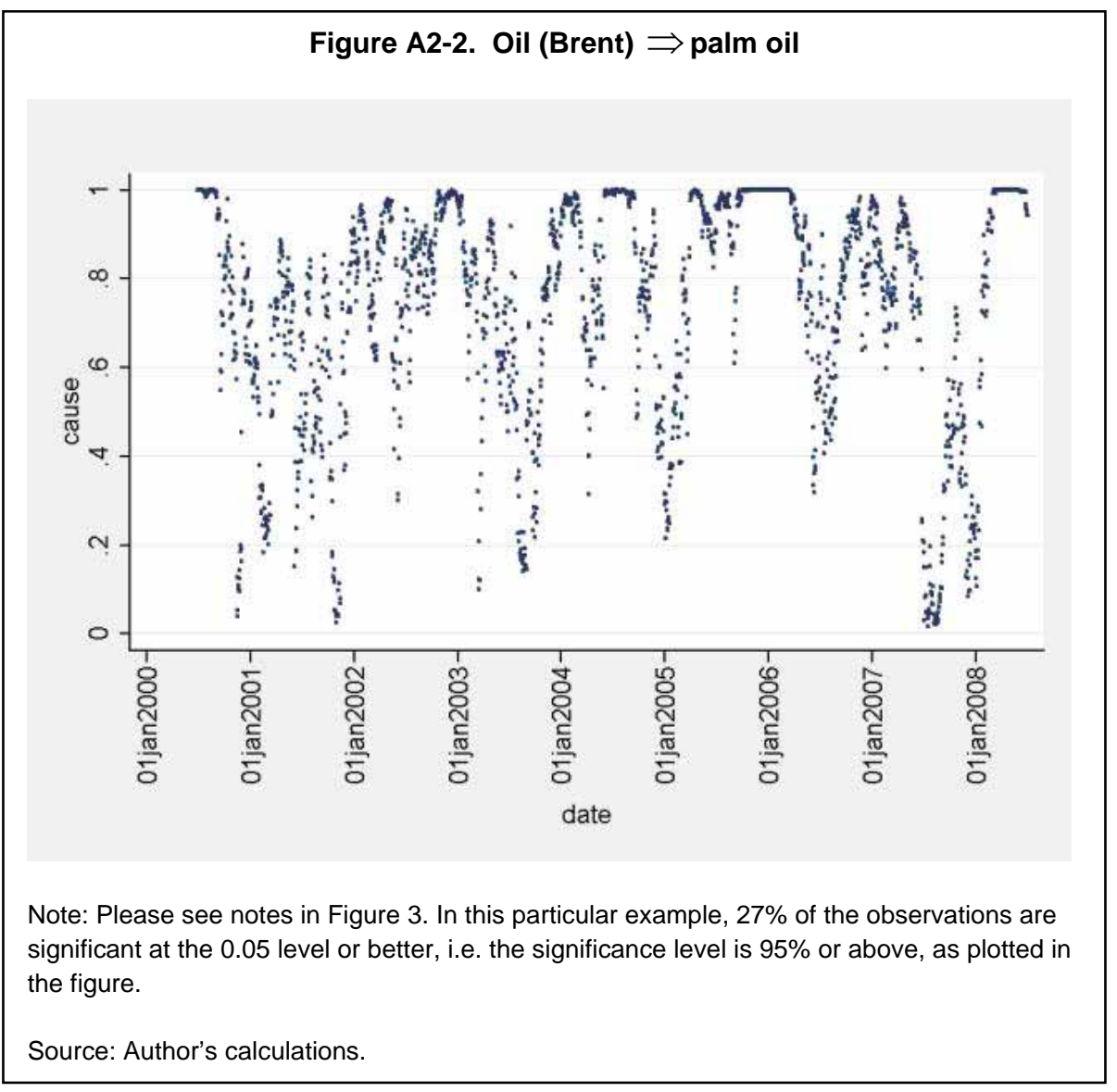




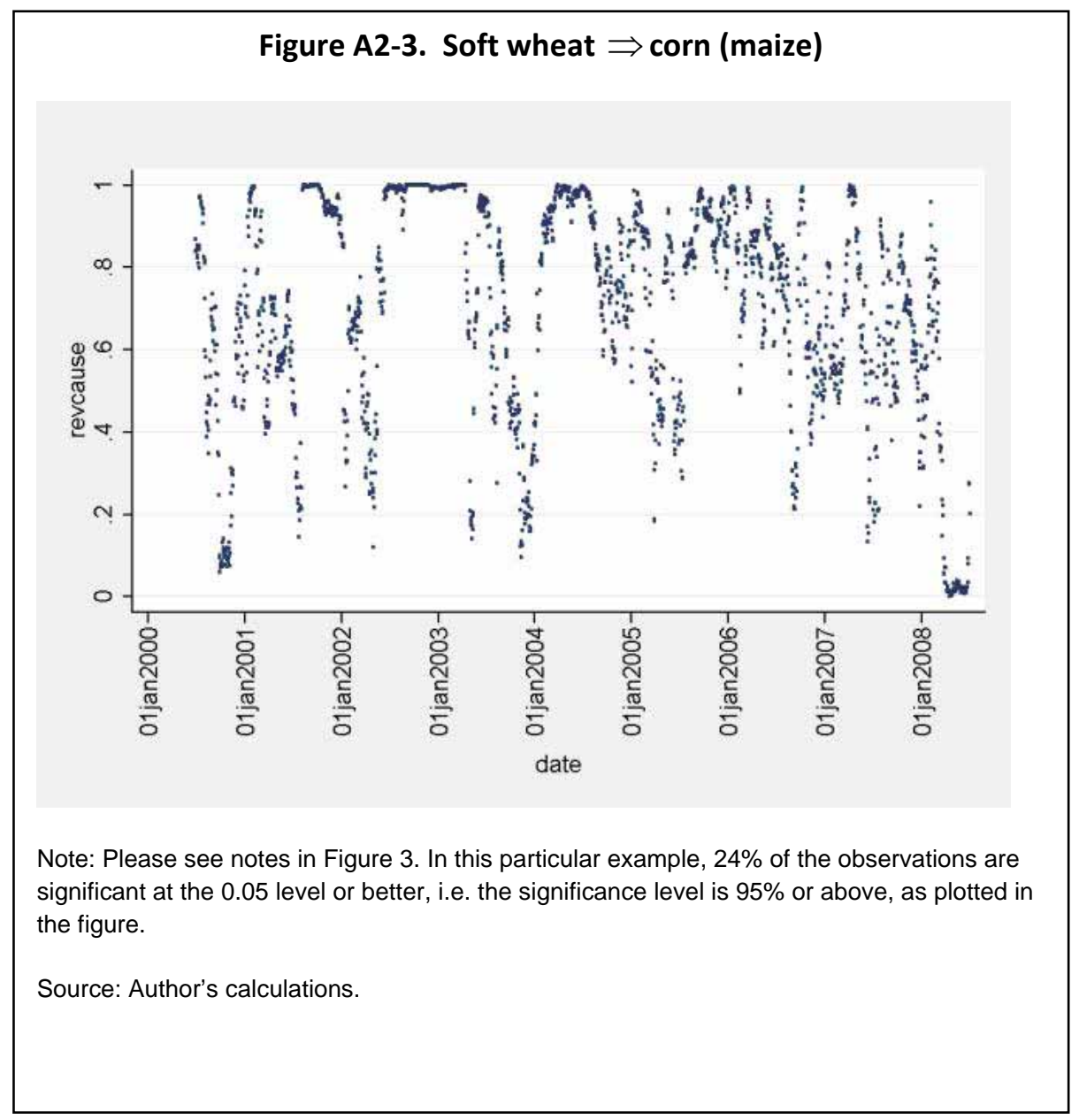




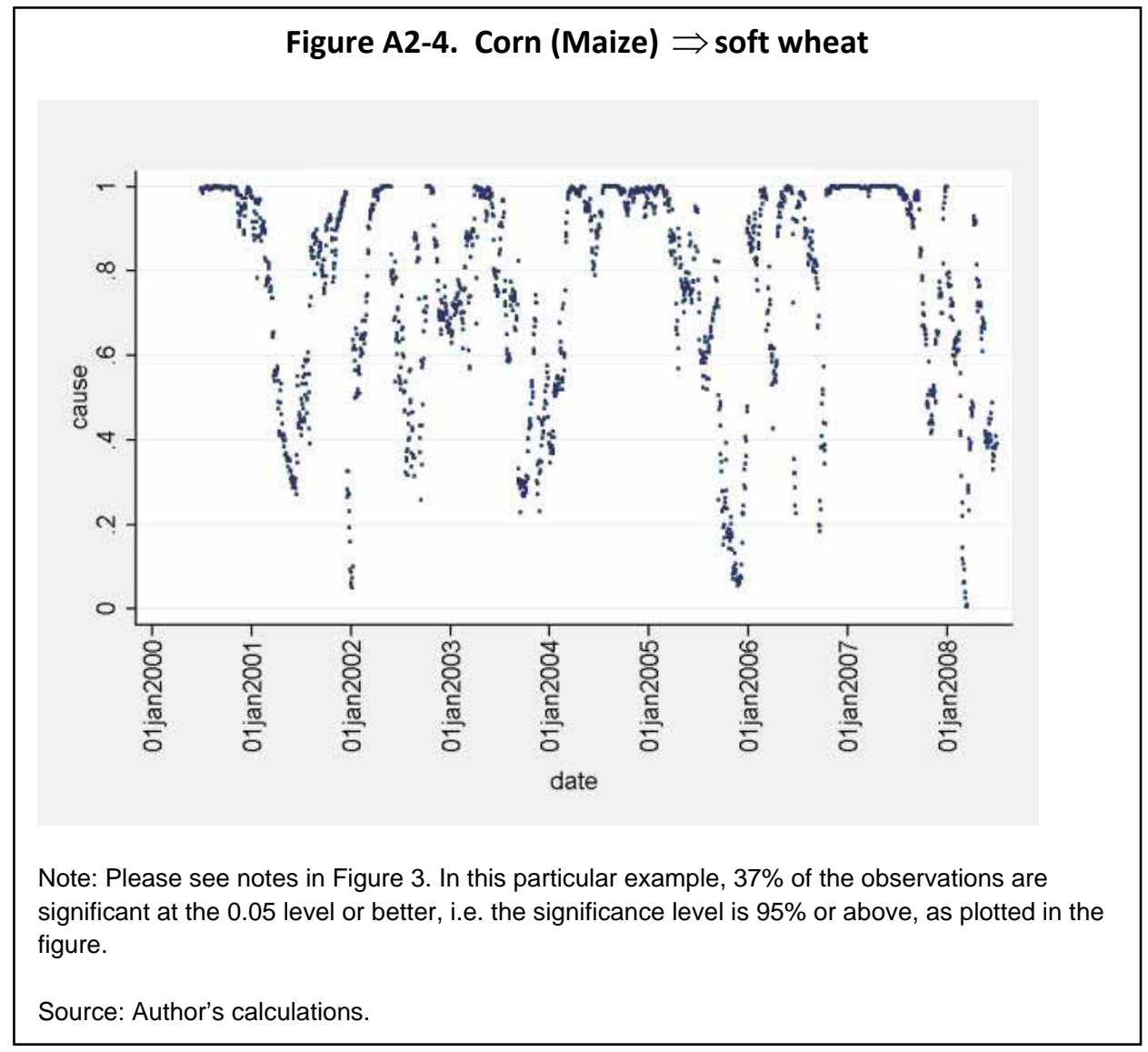


An overview of these linkages, as revealed by the Granger Causality analysis, is shown in Table A2-1. Each cell reports the percentage of significant coefficients for each commodity (in the columns) that is "Granger caused" by the exchange rate or commodity in each row. "Reverse Granger causality" is tested for most commodity pairs as well. Thus daily values of the EU/US FX Rate "cause" the daily prices of Crude Oil 36\% of the time. At the same time, Crude Oil prices "cause" the EU/US FX Rate $26 \%$ of the time.

Understanding the timing of these linkages, and what causes their strength to come and go, is the purpose of the next stage of research.

Table A2-1. Significance of Granger Causality tests for various commodities and the exchange rate between the Euro and US Dollar.

\begin{tabular}{|l|l|l|l|l|l|l|l|}
\hline & $\begin{array}{l}\text { EU/US } \\
\text { FX Rate }\end{array}$ & Crude Oil & Corn & $\begin{array}{l}\text { Hard } \\
\text { Wheat }\end{array}$ & $\begin{array}{l}\text { Soft } \\
\text { Wheat }\end{array}$ & Rice & Palm Oil \\
\hline $\begin{array}{l}\text { EU/US } \\
\text { FX Rate }\end{array}$ & -- & 36 & 30 & 36 & 42 & 47 & 36 \\
\hline Crude Oil & 26 & -- & 26 & $?$ & $?$ & $?$ & 27 \\
\hline Corn & 35 & 49 & -- & 45 & 37 & $?$ & $?$ \\
\hline $\begin{array}{l}\text { Hard } \\
\text { Wheat }\end{array}$ & 28 & $?$ & 38 & -- & $?$ & 33 & $?$ \\
\hline $\begin{array}{l}\text { Soft } \\
\text { Wheat }\end{array}$ & 19 & $?$ & 24 & $?$ & -- & 27 & $?$ \\
\hline Rice & 30 & $?$ & $?$ & 31 & 36 & -- & $?$ \\
\hline Palm Oil & 43 & 28 & $?$ & $?$ & $?$ & $?$ & - \\
\hline
\end{tabular}

Note: Granger Causality for each pair is tested horizontally. Reverse Granger Causality is tested vertically. See text for an example.

A question mark (?) indicates the statistical analyses have not yet been conducted.

Source: Author's calculations 


\section{References}

Abbott, Philip C., Christopher Hurt, and Wallace E. Tyner. 2008. “What’s Driving Food Prices?” Farm Foundation Issue Report (FFIR), Oak Brook, IL. Available: http://www.farmfoundation.org/news/articlefiles/404-FINAL WDFP REPORT 7-2808.pdf.

Barker, Randolph and Robert W. Herdt (with Beth Rose). 1985. The Rice Economy of Asia. Resources for the Future, Washington, DC.

Brahmbhatt, Milan, and Luc Christiaensen. 2008. "Rising Food Prices in East Asia: Challenges and Policy Options.” World Bank, Washington, DC. Available: http://siteresources.worldbank.org/EASTASIAPACIFICEXT/Resources/EA_Rising_Foo d_Prices050508.pdf.

Bray, Francesca. 1986. The Rice Economies: Technology and Development in Asian Societies. Basil Blackwell, Oxford, UK.

Brennan, Michael J. 1958. “The Supply of Storage.” American Economic Review. Vol. 48, No. 1, pp. 50-72. Available:

http://www.econ.kuleuven.be/public/NDBAE55/Brennan\%201958.pdf.

Cootner, Paul H. 1960. "Returns to Speculators: Telser vs. Keynes,” Journal of Political Economy, Vol. 68 (August), pp. 396-404.

. 1961. "Common Elements in Futures Markets for Commodities and Bonds," American Economic Review, Vol. 31 (May), pp. 173-183.

Dawe, David. 2008a. “A note on the (un)importance of world grain stocks for recent world price movements.” FAO. Rome, Italy.

. 2008b. “Lost in Transmission.” Rice Today. July-September, International Rice Research Institute, Los Banos, Philippines, pp. 13-15. Available: http:/www.irri.org/publications/today/pdfs/7-3/RT_Lost_in_Transmission.pdf . 2008c. “Running Out of Steam.” Rice Today. July-September, International Rice Research Institute, Los Banos, Philippines, p. 41. Available: http://www.irri.org/publications/today/pdfs/7-3/RT_Running_out_of_Steam.pdf . 2008d. "Can Indonesia Trust the World Rice Market?” Bulletin of Indonesian Economic Studies. Vol. 44, No. 1 (April), pp. 115-132.

Deaton, Angus, and Guy Laroque. 1992. “On the Behaviour of Commodity Prices.” The Review of Economic Studies. Vol. 59, No. 1 (January), pp. 1-23.

Eberstadt, Nicholas. 2008. “Today’s “Global Food Crisis” in the Mirror of Long Term Development Trends,” presented to U.S. Department of State (November 12), American Enterprise Institute, Washington, DC. 
Falcon, Walter P. and C. Peter Timmer. 1974. "Food: War on Hunger or New Cold War?" (with W.P. Falcon), The Stanford Magazine (Fall/Winter), pp. 4-9, 64

Frankel, Jeffrey. 2006. “The Effect of Monetary Policy on Real Commodity Prices.” NBER Working Paper No. 12713. National Bureau of Economic Research, Cambridge, MA. December. Available: http://www.nber.org/papers/w12713.

Houthakker, Hendrik. 1987. “Futures Trading,” in Eatwell, John, Murray Milgate, and Peter Newman, eds., The New Palgrave: A Dictionary of Economics, Volume 2. MacMillan Press Ltd., London, UK, pp. 447-449.

Kaldor, Nicholas. 1939. “Speculation and Economic Stability.” Review of Economic Studies, Vol. VII (October), pp. 1-27.

Keynes, John Maynard. 1936. The General Theory of Employment, Interest, and Money. Harcourt, Brace Publishing, New York, NY.

Mallaby, Sebastian. 2008. "Rice and Baloney: Irrational Policies the World Over are Making the Food Crisis Worse.” The Washington Post, (Monday, May 18), p. A-17.

Mitchell, Don. 2008. “A Note on Rising Food Prices.” Policy Research Working Paper WPS 4682. World Bank, Washington, DC.

Munier, Bertrand R. 2008. "An X-Ray of the Risk Module within the MOMAGRI Model.” (April) MOMAGRI, Paris, France.

Newbery, David M. G. and Joseph E. Stiglitz. 1981. The Theory of Commodity Price Stabilization: A Study in the Economics of Risk. Clarendon Press, Oxford, UK.

Oshima, Harry T. 1987. Economic Growth in Monsoon Asia: A Comparative Study. University of Tokyo Press, Tokyo, Japan.

Peterson, Willis. 1979. "International Farm Prices and the Social Cost of Cheap Food,” American Journal of Agricultural Economics, Vol. 61, no. 1.

Robles, Miguel, Maximo Torero, and Joachim von Braun. 2009. “When Speculation Matters.” IFPRI Issue Brief 57 (February). International Food Policy Research Institute, Washington, DC.

Salant, Stephen. 1983. “The Vulnerability of Price Stabilization Schemes to Speculative Attack.” Journal of Political Economy. Vol. 91, No. 1 (February), pp. 1-38.

Sanders, Dwight H., and Scott H. Irwin. 2008. “Futures Imperfect.” New York Times, July 20, p. 12wk. Available: http://www.nytimes.com/2008/07/20/opinion/20irwinsanders.html?_r=1\&oref=slogin

Shiller, Robert J. 1992. Market Volatility. MIT Press. Cambridge, MA. 
Slayton, Tom. 2009. "Rice Crisis Forensics: How Asian Governments Carelessly Set the World Rice Market on Fire.” CGD Working Paper 163. Washington, DC: Center for Global Development.

Slayton, Tom and C. Peter Timmer. 2008. "Japan, China and Thailand Can Solve the Rice Crisis—But U.S. Leadership is Needed.” CGD Notes (May), Center for Global Development, Washington, DC.

Telser, Lester G. 1958. "Futures Trading and the Storage of Cotton and Wheat.” Journal of Political Economy. Vol. 66 (June), pp. 233-255.

Timmer, C. Peter. 1984. "Energy and Structural Change in the Asia-Pacific Region: The Agricultural Sector," in Romeo M. Bautista and Seiji Naya, Energy and Structural Change in the Asia-Pacific Region: Papers and Proceedings of the Thirteenth Pacific Trade and Development Conference (Manila: Philippine Institute for Development Studies and the Asian Development Bank, 1984), pp. 51-72.

, ed. 1987. The Corn Economy of Indonesia. Ithaca: Cornell University Press. . 1989. "Food Price Policy: The Rationale for Government Intervention." Food Policy, vol. 14, no. 1 (February), pp. 17-27.

. 1991. "Food Price Stabilization: Rationale, Design, and Implementation," in Dwight H. Perkins and Michael Roemer, eds., Reforming Economic Systems. (Cambridge: Harvard Institute for International Development, Harvard University. Distributed by Harvard University Press), pp. 219-48 and pp. 456-59.

. 1996. "Does BULOG Stabilize Rice Prices in Indonesia? Should It Try?" Bulletin of Indonesian Economic Studies (Canberra), vol. 32, no. 2 (August), pp. 45-74.

. 2000. "The Macro Dimensions of Food Security: Economic Growth, Equitable Distribution, and Food Price Stability." Food Policy, vol. 25, no. 4 (August), pp. 283-295.

. 2008a. "Causes of High Food Prices.” Chapter 2.3 in Asian Development Outlook Update (September), Asian Development Bank, Manila.

. 2008b. "Causes of High Food Price” plus Technical Annexes. ADB

Economics Working Paper Series No. 128 (October), Asian Development Bank, Manila.

. 2009. “Did Speculation Affect World Rice Prices?” ESA/FAO Working

Paper 09-07, Food and Agricultural Organization, Rome, Italy.

Timmer, C. Peter and Walter P. Falcon. 1975. "The Political Economy of Rice Production and Trade in Asia," in Lloyd Reynolds, ed., Agriculture in Development Theory (New Haven: Yale University Press), pp. 373-408.

Timmer, C. Peter, Walter P. Falcon and Scott R. Pearson. 1983. Food Policy Analysis. Johns Hopkins University Press for the World Bank, Baltimore, MD. 
Timmer, C. Peter, and David Dawe. 2007. "Managing Food Price Instability in Asia: A Macro Food Security Perspective.” Asian Economic Journal. Vol. 21, No. 1, pp. 1-18.

Trostle, Ronald. 2008. "Global Agricultural Supply and Demand: Factors Contributing to the Recent Increase in Food Commodity Prices.” Economic Research Service, Outlook Report No. WRS-0801. Washington: US Department of Agriculture, May. Available: http://www.ers.usda.gov/Publications/WRS0801/WRS0801.pdf

Weymar, F. Helmut. 1968. The Dynamics of the World Cocoa Market. MIT Press. Cambridge, MA.

Wickizer, Vernon D., and Merrill K. Bennett. 1941. The Rice Economy of Monsoon Asia. Food Research Institute, Stanford University, Stanford, CA. in cooperation with the Institute of Pacific Relations.

Working, Holbrook. 1933. "Price Relations between July and September Wheat Futures at Chicago since 1885.” Wheat Studies. Vol. 9 (March), pp. 187-238.

. 1948. "Theory of the Inverse Carrying Charge in Futures Markets.” Journal of Farm Economics. Vol. 30 (February), pp. 1-28. . 1949. "The Theory of the Price of Storage.” American Economic Review. Vol. 31 (December), pp. 1254-1262.

Williams, Jeffrey C., and Brian D. Wright. 1991. Storage and Commodity Markets. Cambridge, United Kingdom: Cambridge University Press. 